William \& Mary Law School

William \& Mary Law School Scholarship Repository

\title{
Class Actions, Heightened Commonality, and Declining Access to Justice
}

\author{
A. Benjamin Spencer \\ spencer@wm.edu
}

Follow this and additional works at: https://scholarship.law.wm.edu/facpubs

Part of the Civil Procedure Commons, Litigation Commons, and the Supreme Court of the United States Commons

\section{Repository Citation}

Spencer, A. Benjamin, "Class Actions, Heightened Commonality, and Declining Access to Justice" (2013). Faculty Publications. 1976.

https://scholarship.law.wm.edu/facpubs/1976

Copyright c 2013 by the authors. This article is brought to you by the William \& Mary Law School Scholarship Repository.

https://scholarship.law.wm.edu/facpubs 


\title{
CLASS ACTIONS, HEIGHTENED COMMONALITY, AND DECLINING ACCESS TO JUSTICE
}

\author{
A. BENJAMin SPENCER*

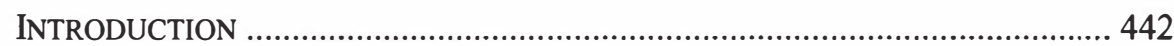 \\ I. THE ROOTS OF COMMONALITY ……...................................................... 449 \\ A. The Antecedents of Rule 23 ................................................... 450 \\ 1. The Precursors of the Common Right Requirement.............. 452 \\ 2. The Origin of the "Common Question" Requirement............ 455 \\ 3. The Contradistinction Between Common Questions \\ and Common Rights................................................................ 458 \\ B. The Modern Version of Rule 23..................................................... 461 \\ II. DUKES AND THE DEVELOPMENT OF HEIGHTENED COMMONALITY .... 463 \\ A. The Same Injury Requirement ...................................................... 464 \\ B. The Centrality Requirement ......................................................... 470 \\ C. The Efficiency Requirement .......................................................... 473 \\ III. HEIGHTENED COMMONALITY AND THE RESTRICTIVE ETHOS IN

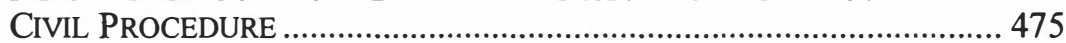

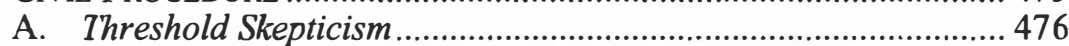 \\ B. Disfavored Actions ....................................................................... 479 \\ C. Anti-Claimant Bias and Outgroups as Class Claimants .............. 484

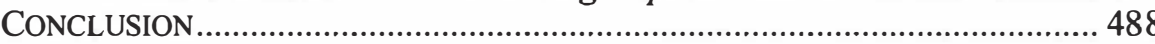

A prerequisite to being certified as a class under Rule 23 of the Federal Rules of Civil Procedure is that there are "questions of law or fact common to the class." Although this "commonality" requirement had heretofore been regarded as something that was easily satisfied, in Wal-Mart Stores, Inc. v. Dukes the Supreme Court gave the requirement new vitality by reading into it an obligation to identify among the class a common injury and common questions that are "central" to the dispute. Not only is such a reading of Rule 23 's commonality requirement unsupported by the text of the rule, but it also is at odds with the historical understanding of commonality in both the class action and joinder contexts. The Court's articulation of a heightened commonality standard can be explained by a combination of its negative view

- Associate Dean for Research, Frances Lewis Law Center Director \& Professor of Law, Washington \& Lee University School of Law. I am grateful for the funding support this work has received from the Frances Lewis Law Center, as well as for the helpful comments of individual colleagues, especially those who participated in the Mercer Langston Faculty Writing Workshop at Suffolk University Law School in June 2012. Finally, I am thankful for the research assistance provided by the reference librarians at the University of Virginia School of Law, where I resided during part of the time spent developing this Article. 
of the merits of the discrimination claims at issue in Dukes, the conflation of the predominance requirement with commonality, and the Court's apparent penchant for favoring restrictive interpretations of procedural rules that otherwise promote access. Although an unfortunate consequence of the Dukes Court's heightening of the commonality standard will be the enlivening of challenges to class certifications that would otherwise never have been imagined, this Article urges the Court to reject heightened commonality and read Rule 23 in a manner that remains true to the language and history of the common question requirement.

\section{INTRODUCTION}

\section{"The text is the law, and it is the text that must be observed." - Justice Antonin Scalia ${ }^{1}$}

The class certification decision is one of the most hard-fought battles in civil litigation. Aggregating many claims in a single action can threaten defendants with immense liability, a threat that can be reduced or avoided altogether when prospective plaintiffs are denied the opportunity to pursue their claims collectively. This battle has been waged primarily under Rule 23 over concerns such as mootness, ${ }^{2}$ notice, ${ }^{3}$ predominance, ${ }^{4}$ and adequacy of representation. ${ }^{5}$ Whether monetary relief can be properly sought in the context of an injunctiverelief class certified under Rule 23(b)(2) has also been a point of contention. ${ }^{6}$

\footnotetext{
${ }^{1}$ Antonin Scalia, Common-Law Courts in a Civil-Law System: The Role of United States Federal Courts in Interpreting the Constitution and Laws, in A MATTER Of INTERPRETATION: FEDERAL COURTS AND THE LAW 3, 22 (Amy Gutmann ed., 1997).

2 See, e.g., Deposit Guar. Nat'l Bank v. Roper, 445 U.S. 326, 333 (1980) (holding that appeal of denial of class certification is not mooted by tender of settlement offer and entry of judgment, so long as time for appeal has not expired); Sosna v. Iowa, 419 U.S. 393, 401 (1975) (holding that resolution of the controversy of the class representative after commencement of the action does not moot the dispute with respect to the class).

${ }^{3}$ See, e.g., Eisen v. Carlisle \& Jacquelin, 417 U.S. 156, 176, 178 (1974) (holding that "individual notice to identifiable class members is not a discretionary consideration to be waived in a particular case" and that "[t]he usual rule is that a plaintiff must initially bear the cost of notice to the class"); see also Oppenheimer Fund, Inc. v. Sanders, 437 U.S. 340, 356-59 (1978) (recognizing there may be circumstances where it is appropriate to shift to the defendant the costs associated with providing notice to the class).

${ }^{4}$ See, e.g., Amchem Prods., Inc. v. Windsor, 521 U.S. 591, 622 (1997) (holding that common questions did not predominate over individual ones in a proposed settlement class involving plaintiffs exposed to asbestos products supplied by the defendant).

${ }^{5}$ See, e.g., id. at 625-26 (holding, in attempted asbestos exposure litigation, that currently injured plaintiffs cannot adequately represent exposure-only plaintiffs due to a conflict among their respective compensation goals).

${ }^{6}$ See, e.g., Allison v. Citgo Petrol. Corp., 151 F.3d 402, 415 (5th Cir. 1998) (“ $[\mathrm{M}]$ onetary relief predominates in (b)(2) class actions unless it is incidental to requested injunctive or declaratory relief."); Williams v. Owens-Illinois, Inc., 665 F.2d 918, 928-29
} 
What has heretofore not been the subject of the same degree of controversy, however, is the issue of whether a proposed class had questions of law or fact in common as required for class certification under Rule 23(a)(2). ${ }^{7}$ That changed in 2011 when the Supreme Court decided Wal-Mart Stores, Inc. $v$. Dukes ${ }^{8}$ in which it held that a putative employment-discrimination class did not satisfy this "commonality" requirement. 9

Commonality, which refers to the requirement that "there are questions of law or fact common to the class," 10 is a prerequisite to class certification that, prior to Dukes, had been seen as relatively easy to satisfy. ${ }^{11}$ It requires that each member of the class assert claims that share legal or factual issues with one another. For example, if there were a group of consumers, each of whom had experienced the same product defect, a common factual question uniting the class would be whether the product had an alleged defect; 12 a common legal question in this scenario might be whether the defendant owed and breached a duty of care to the plaintiffs or negligently failed to warn them. ${ }^{13}$ In short, identifying a factual determination to be made or a legal issue to be

(9th Cir. 1982) ("[T]his court has adopted the view that legal remedies which are incidental to a request for injunctive relief may be included as a part of the (b)(2) claim.").

7 Although the Supreme Court addressed the typicality and commonality requirements of Rule 23(a) in General Telephone Co. of the Southwest v. Falcon, 457 U.S. 147 (1982), which featured a commonality analysis that was clouded by its integration with the typicality analysis, it was not until Dukes that the Court revisited commonality. Many cases in the Rule 23(b)(3) damages class context dispense with an independent commonality analysis and proceed directly to the issue of whether such common questions predominate over individual ones, with the antecedent issue of commonality not being a real point of contention. See, e.g., Lienhart v. Dryvit Sys., Inc., 255 F.3d 138, 146 n.4 (4th Cir. 2001). The Supreme Court has endorsed this approach. See Amchem Prods., 521 U.S. at 609 ("Rule 23(a)(2)'s 'commonality' requirement is subsumed under, or superseded by, the more stringent Rule 23(b)(3) requirement that questions common to the class 'predominate over' other questions. The court therefore trained its attention on the 'predominance' inquiry." (quoting Georgine v. Amchem Prods., Inc., 83 F.3d 610, 627 (3d Cir. 1996))).

8 131 S. Ct. 2541 (2011).

9 Id. at 2556-57.

10 FED. R. CIV. P. 23(a)(2).

115 James WM. Moore et Al., Moore’s Federal Practice § 23.23[2] (Mathew Bender ed., 3d ed. 2011) ("Because commonality requires only one common question of law or fact, some courts have written that the commonality requirement is easily satisfied.").

12 Saltzman v. Pella Corp., 257 F.R.D. 471,478 (N.D. Ill. 2009) (identifying as a common factual question in the case "whether and when Pella ProLine Windows suffered from an inherent wood 'durability' defect").

13 Jones v. Allercare, Inc., 203 F.R.D. 290, $298-99$ (N.D. Ohio 2001) ("The issues of defendant's defective formulation or design of the Powder and Spray and its failure to provide reasonable warnings or instructions concerning the products are common to all those allegedly injured by the Powder and/or Spray."). 
resolved that was germane to the claims asserted by each class member had been sufficient to meet the commonality standard of Rule 23(a)(2). ${ }^{14}$

The Dukes majority saw things differently. It was faced with "one of the most expansive class actions ever," consisting of roughly 1.5 million plaintiffs who were current and former female employees of Wal-Mart. ${ }^{15}$ In a nutshell, the plaintiffs alleged that Wal-Mart had policies that permitted local supervisors to make pay and promotion decisions subjectively, which "operated as a vehicle for perpetrating gender bias in its pay and promotion decisions."16 As a result, it was argued, female employees suffered from discriminatory pay and promotion decisions, making Wal-Mart liable for "engag[ing] in a pattern or practice of discrimination in violation of Title VII's prohibition on disparate treatment." 17 The plaintiffs also challenged WalMart's subjective practices "under the disparate impact theory of discrimination."18 Under these circumstances, the Dukes majority found the requisite common questions completely lacking. It reached this result by redefining commonality. The majority stated that merely raising a common question "is not sufficient to obtain class certification." 19 Commonality requires rather that the plaintiffs share the "same injury" raising "a common contention," the determination of which will resolve an issue that is "central" to each of the claims. ${ }^{20}$ These attributes of commonality set forth by the majority provide a basis to believe that all of the claims "can productively be litigated at once."21

Nothing in the language or history of Rule 23(a)(2) supports the Dukes majority's interpretation of it. ${ }^{22}$ Rule 23(a)'s commonality language says

\footnotetext{
${ }^{14}$ Note that although the language of Rule 23(a)(2) requires "questions" of law or fact in common, this plural use of the word has not been interpreted to require that there be multiple common questions. See, e.g., 1 Alba Conte \& Herbert B. Newberg, NewberG ON Class ACtıons $\S 3: 20$ (William B. Rubenstein ed., 5th ed. 2011) ("The commonality test is more qualitative than quantitative, and thus, there need be only a single issue common to all members of the class."). The Dukes majority did not disturb this interpretation. See Dukes, 131 S. Ct. at 2556 ("We quite agree that for purposes of Rule 23(a)(2) even a single common question will do." (internal quotation marks omitted)).

15 Dukes, 131 S. Ct. at 2547.

16 Brief for Respondents at 1-2, Dukes, 131 S. Ct. 2541 (No. 10-277). The plaintiffs also alleged unlawful retaliation under Title VII. Plaintiffs' Third Amended Complaint at 23, Dukes v. Wal-Mart Stores, Inc., 222 F.R.D. 137 (N.D. Cal. 2004) (No. C-01-2252).

17 Brief for Respondents, supra note 16, at 9 (citing 42 U.S.C. $§ 2000 \mathrm{e}-2$ (a) (2006); Int'l Bhd. of Teamsters v. United States, 431 U.S. 324, 336-38 (1977)).

18 Id. at 10 (citing 42 U.S.C. $\S 2000 \mathrm{e}-2(\mathrm{k})$; Watson v. Fort Worth Bank \& Trust, 487 U.S. 977, 989-91 (1988)).

${ }^{19}$ Dukes, $131 \mathrm{~S}$. Ct. at 2551.

${ }^{20}$ Id.

${ }^{21}$ Id.

22 Dean Klonoff expresses the same view when he writes, "The majority decision in Dukes cannot be squared with the text, structure, or history of Rule 23(a)(2). Nothing in the
} 
nothing of the nature or import of the legal or factual questions that class members' claims must share, nor does it mandate that class plaintiffs be bound together by the "same injury." The only requirement of commonality is that common questions exist. How, then, did the Dukes majority derive its novel formulation of "heightened commonality"? ${ }^{23}$ Claimant animus, combined with hostility toward and a misunderstanding of claims of discrimination, incented the majority to infuse the commonality requirement with a set of class propriety concerns - unity of injury and the importance of the common questions - it was not designed to police. The result is not an exercise in rule interpretation, but rather yet another demonstration of the Court's willingness of late to place policy above principle in ways that restrict access to justice. ${ }^{24}$

This is a potentially alarming development, as jurists spar over the import and application of Dukes to the commonality questions before them ${ }^{25}$ and with some, though certainly not all, ${ }^{26}$ lower courts taking the heightened

text of Rule 23(a)(2), or in the Advisory Committee Notes thereto, requires that the common question be central to the outcome." Robert H. Klonoff, The Decline of Class Actions, 90 WASH. U. L. REV. (forthcoming March 2013).

${ }^{23}$ This Article uses this term to refer to the new commonality standard that requires class members to have the same injury, that common questions be central to the litigation, and that resolution of the common issues creates significant litigation efficiencies. This is distinct from how some have referred to Rule 23(b)(3)'s predominance requirement as a "heightened commonality" requirement. See Thomas v. Baca, 231 F.R.D. 397, 402 (C.D. Cal. 2005) (" $[\mathrm{T}]$ his [predominance] requirement is essentially a heightened commonality inquiry: do the common legal and factual questions appear more significant than the individualized legal and factual questions?"); Geoffrey P. Miller, Payment of Expenses in Securities Class Actions: Ethical Dilemmas, Class Counsel, and Congressional Intent, 22 REV. LITIG. 557, 583 (2003) ("The predominance requirement is in effiect a heightened commonality rule, demanding that questions of law or fact in some sense form the center of gravity of the litigation, or that they will occupy the bulk of the court's or the litigants' time and efforts.").

${ }^{24}$ For a discussion of this trend, see infra Part III.

${ }^{25}$ Sullivan v. DB Invs., Inc., 667 F.3d 273, 344 (3d Cir. 2011) (Jordan, J., dissenting) ("In stark contrast to the Majority's practically limitless definition of commonality is the measured definition provided by the Supreme Court in its recent decision in Wal-Mart Stores, Inc. v. Dukes."); Gray v. Hearst Comm'ns, Inc., 444 F. App'x 698, 703-04 (4th Cir. 2011) (Wilkinson, J., dissenting) ("With respect, the majority is mistaken in its attempt to distinguish Wal-Mart on the basis of White Directory's uniform distribution practice. . . . Wal-Mart is squarely on point. . . As in Wal-Mart, White Directory's sales policy was one of broad discretion." (internal quotation marks omitted)).

${ }^{26}$ Some courts have been more circumspect in their understanding of Dukes, limiting the decision to its facts. See, e.g., McReynolds v. Merrill Lynch, Pierce, Fenner \& Smith, Inc., 672 F.3d 482, 488 (7th Cir. 2012) ("Wal-Mart holds that if employment discrimination is practiced by the employing company's local managers, exercising discretion granted them by top management . . . rather than implementing a uniform policy established by top management to govern the local managers, a class action by more than a million current and former employees is unmanageable; the incidents of discrimination complained of do not 
commonality approach to heart. ${ }^{27}$ For example, in M.D. ex rel. Stukenberg $v$. Perry, ${ }^{28}$ a suit seeking "to redress alleged class-wide injuries caused by systemic deficiencies in Texas's administration of [it's foster care program],"19 the court announced that Dukes had fundamentally changed the standard for commonality:

present a common issue that could be resolved efficiently in a single proceeding."); Ross $\mathbf{v}$. RBS Citizens, N.A., 667 F.3d 900, 902-03 (7th Cir. 2012) (distinguishing Dukes based on the presence of an alleged uniform policy of the defendant to deny overtime pay); Labriola v. Bank of Am., N.A., No. C 12-79, 2012 WL 1657191, at *9 (N.D. Cal. May 10, 2012) ("While, in its motion, Defendant states that 'no commonality exists as a matter of law,' Defendant's arguments actually relate to whether common questions predominate, not whether any common questions exist at all. On the face of the [first amended complaint], Plaintiff has identified at least one common question: whether Defendant had a policy and practice of delaying payment of final wages. ... This question can be resolved on a classwide basis, and the common answer is apt to drive resolution of the litigation." (citation omitted) (citing Dukes, $131 \mathrm{~S}$. Ct. at 2556)); Youngblood v. Family Dollar Stores, Inc., No. 09 Civ. 3176, 2011 WL 4597555, at *4 (S.D.N.Y. Oct. 4, 2011) ("Unlike the claims in WalMart[,] Plaintiffs' [] claims do not require an examination of the subjective intent behind millions of individual employment decisions; rather, the crux of this case is whether the company-wide policies, as implemented, violated Plaintiffs' statutory rights." (internal quotation marks omitted)).

${ }^{27}$ See, e.g., Jamie S. v. Milwaukee Pub. Schs., 668 F.3d 481, 493, 497-98 (7th Cir. 2012) (finding that class plaintiffs failed to establish commonality under the Dukes standard in an action alleging the failure to ensure children's rights under the Individuals with Disabilities in Education Act); Haggart v. Endogastric Solutions, Inc., No. 10-346, 2012 WL 2513494, at *4 n.5 (W.D. Pa. June 28, 2012) ("While it appears that there could certainly be common issues resolvable in a way that would move the litigation forward . . . and/or common questions of law, it also appears that class members have not suffered the same class of injury and that commonality would therefore not be met under Dukes." (emphasis omitted) (citation omitted)); Rowe v. Bankers Life \& Cas. Co., No. 09-cv-491, 2012 WL 1068754, at *5 (N.D. Ill. Mar. 29, 2012) ("[T]he Supreme Court's decision in Wal-Mart Stores, Inc. v. Dukes has made the question of whether the nationwide class satisfies the commonality requirement in Rule 23(a) a more challenging one ... ."); In re Heartland Payment Sys., Inc. Customer Data Sec. Breach Litig., 851 F. Supp. 2d 1040, 1052 (S.D. Tex. 2012) ("Under previous Fifth Circuit precedent, commonality required 'one common question of law or fact' to the class. In Wal-Mart Stores, Inc. v. Dukes, the Supreme Court held that the mere 'raising of common "questions" of law or fact' is no longer sufficient." (citations omitted) (quoting James v. City of Dallas, 254 F.3d 551, 570 (5th Cir. 2001); Dukes, 131 S. Ct. at 2551)); In re Motor Fuel Temperature Sales Practices Litig., 279 F.R.D. 598, 607 (D. Kan. 2012) ("Dukes is relevant because it arguably heightened the commonality requirement under Rule 23(a) and narrowed the permissible scope of a Rule 23(b)(2) class."); see also, e.g., Munoz v. Giumarra Vineyards Corp., No. 1:09-cv-00703, 2012 WL 2617553, at *19 (E.D. Cal. July 5, 2012) (applying Dukes's "same injury" requirement to find the requisite commonality under Rule 23(a)(2)).

${ }^{28} 675$ F.3d 832 (5th Cir. 2012).

${ }^{29}$ Id. at 835 . 
[T] he commonality test is no longer met when the proposed class merely establishes that "there is 'at least one issue whose resolution will affect all or a significant number of the putative class members." Rather, Rule 23(a)(2) requires that all of the class member's claims depend on a common issue of law or fact whose resolution "will resolve an issue that is central to the validity of each one of the [class member's] claims in one stroke." 30

As a result, even though the district court found a common question of fact to be "whether Defendants failed to maintain a caseworker staff of sufficient size and capacity to perform properly," the circuit panel found this insufficient to satisfy the commonality requirement. ${ }^{31}$ The stated reason was that the "district court failed to describe how a finding that Texas fails to maintain a caseworker staff that performs 'properly' will resolve an issue that is 'central to the validity of each one of the [class member's] claims in one stroke." 32 If an increasing number of courts embrace the heightened commonality standard of Dukes, class certification will become more difficult, something that will reduce the deterrent effect of the class action device. ${ }^{33}$ Further, because the common question requirement appears in other rules pertaining to joinder ${ }^{34}$ and consolidation of actions, ${ }^{35}$ heightening commonality under Rule 23 promises to bleed into these other areas, making aggregating litigation more difficult beyond the class action context. Indeed, litigants have begun arguing that Dukes's heightened commonality standard should be applied beyond class actions to the "similarly situated" requirement for collective actions brought

${ }^{30}$ Id. at 840 (alteration in original) (quoting Forbush v. J.C. Penney Co., 994 F.2d 1101, 1106 (5th Cir. 1993); Dukes, 131 S. Ct. at 2551).

${ }^{31}$ Id. at 841.

32 Id. (quoting Dukes, $131 \mathrm{~S}$. Ct. at 2551).

${ }^{33}$ Suzette M. Malveaux, How Goliath Won: The Future Implications of Dukes v. WalMart, 106 Nw. U. L. Rev. ColloquY 34, 44-45 (2011), http://www.law.northwestern.edu/la wreview/colloquy/2011/18/LRColl2011nl8Malveaux.pdf ("[T]o satisfy commonality generally, judges may now require a stronger causal connection between an employer's discretionary decisionmaking policy and a disparity or adverse employment action. This shift will make it harder for employees relying on this theory to act collectively." (footnote omitted)); George Rutherglen, Wal-Mart, AT\&T Mobility, and the Decline of the Deterrent Class Action, 98 V A. L. REv. IN BRIEF 24, 29 (2012), http://www.virginialawreview.org//inbr ief.php?s=inbrief\&p=2012/04/14/post ("In sum, the holding on commonality in Wal-Mart diminishes the prospect of certification and in doing so, diminishes the likelihood that a class action will be brought. The net effect is to reduce the defendant's exposure to classwide liability and the deterrent effiect of class actions generally.").

34 See FED. R. CIV. P. 20(a) (requiring that there be a common question of law or fact for party joinder); FED. R. CIV. P. 24(b) (requiring the same for permissive intervention).

35 See 28 U.S.C. $\S 1407$ (a) (2006) (requiring that there be a common question of law or fact for handling separate actions jointly during the pretrial phase under the multidistrict litigation statute); FED. R. CIV. P. 42(a) (requiring the same for consolidation of actions for trial). 
under the Fair Labor Standards Act. ${ }^{36}$ Some courts, ${ }^{37}$ but not all, ${ }^{38}$ have embraced these arguments.

Dukes's heightened commonality standard is also disquieting in light of the Court's other recent decisions trending in the direction of restricting access to justice by making it more difficult for plaintiffs to bring claims and have them heard. From the loosening of summary judgment standards ${ }^{39}$ to the heightening of pleading obligations, ${ }^{40}$ getting in the courthouse door and to a consideration of the merits of one's claim has become increasingly difficult. Although class actions had certainly not been an area in which the road to the courthouse was free and clear, ${ }^{41}$ expanding the battlefield beyond the areas of traditional concern into the commonality inquiry is a bridge too far. Some members of Congress have already recognized this and introduced legislation designed to overcome the Court's limiting interpretation of commonality by creating a new

3629 U.S.C. $§ 216$ (b) (2006) ("An action to recover the liability prescribed in either of the preceding sentences may be maintained against any employer (including a public agency) in any Federal or State court of competent jurisdiction by any one or more employees for and in behalf of himself or themselves and other employees similarly situated."); see also, e.g., Moore v. Publicis Groupe SA, No. 11 Civ. 1279, 2012 WL 2574742, at *12 (S.D.N.Y. June 29, 2012) ("Defendants also argue that though Fed. R. Civ. P. 23 is not applicable to collective actions, the 'commonality' standard set forth in Rule 23(a) is analogous to the 'similarly situated' requirement in section 216(b). . . . Defendants argue that the [Dukes] standard should be applied here . ...").

37 See, e.g., Scott v. Family Dollar Stores, Inc., No. 3:08CV540, 2012 WL 113657, at *4 (W.D.N.C. Jan. 13, 2012) (holding that the "similarly situated" standard under $\S 216(\mathrm{~b})$ and the commonality standard under Rule 23(a)(2) are "nearly identical" and thus the Dukes interpretation of commonality is relevant in the FLSA context); Ruiz v. Serco, Inc., No. 10cv-394, 2011 WL 7138732, at *6-7 (W.D. Wis. Aug. 5, 2011) (indicating that Dukes is instructive in FLSA cases); MacGregor v. Farmers Ins. Exch., No. 2:10-CV-03088, 2011 WL 2981466, at *4 (D.S.C. Jul. 22, 2011) (taking guidance from Dukes when deciding a collective action motion).

38 See, e.g., Winfield v. Citibank, N.A., 843 F. Supp. 2d 397, 409 (S.D.N.Y. 2012) (holding that, notwithstanding Dukes, "the stringent requirements for class certification under Rule 23 are not identical to the minimal burden that plaintiffs carry on a motion for conditional certification under § 216(b)"); Pippins v. KPMG LLP, No. 11 Civ. 0377, 2012 WL 19379, at *7 (S.D.N.Y. Jan. 3, 2012).

39 Celotex Corp. v. Catrett, 477 U.S. 317, 323 (1986); Anderson v. Liberty Lobby, Inc., 477 U.S. 242, 257 (1986); Matsushita Elec. Indus. Co. v. Zenith Radio Corp., 475 U.S. 574, 583 (1986).

40 Ashcroft v. Iqbal, 556 U.S. 662, 687 (2009); Bell Atlantic Corp. v. Twombly, 550 U.S. 544, 570 (2007).

${ }^{41}$ Significant certification hurdles characterize the landscape here. Amchem and Ortiz $v$. Fibreboard Corp., 527 U.S. 815 (1999), are noted for having increased the difficulties associated with certifying nationwide personal injury classes. See Samuel Issacharoff, Private Claims, Aggregate Rights, 2008 SuP. CT. REV. 183, 208 ("As a result [of Amchem and Ortiz], class actions seemed to drop out of the available set of tools for attempting to settle most mass torts ...."). 
"group action" device for those challenging discrimination in employment. The device would permit circumvention of subparagraphs (a) and (b) of Rule 23 and would dispense with any commonality requirement. ${ }^{42}$

The aim of this Article is to challenge the Supreme Court's misreading of the commonality requirement before it takes root by illustrating its impropriety and potentially pernicious effects. To fully understand the error of the Dukes majority's interpretation of commonality, it is useful to begin by exploring the origins of Rule 23's common question requirement and how that language has been traditionally understood and applied. Part I undertakes this task. It reveals that the Dukes interpretation improperly unites and confuses repudiated and historically distinct concepts - the notion of common rights or injuries versus common questions of law or fact - not intended to be part of today's common question requirement. Armed with this knowledge, Part II turns to a direct consideration of the interpretive errors reflected in the Dukes commonality holding. Beyond being at odds with the historical development of the text, the interpretation is deficient for its very departure from the text of Rule 23 , as well as for its reliance on twisted understandings of precedent and its conflation of Rule 23(b)(3)'s predominance requirement with Rule 23(a)(2)'s commonality provision. Having laid bare the defects of the Dukes interpretation of commonality, Part III theorizes why the Dukes majority took the position that it did. It argues that the creation of heightened commonality is a definitive example of a larger trend of declining access to civil justice. This trend reflects what I have previously described as a restrictive ethos in civil procedure ${ }^{43}$ The restrictive ethos thesis is that the Court uses access-restricting interpretations of procedural rules to thwart disfavored claims asserted by members of disempowered groups against members of the dominant class, such as major corporations.

\section{THE ROOTS OF COMMONALITY}

In Dukes, Justice Scalia offers a new vision of the commonality requirement of Rule 23(a)(2): class plaintiffs must be united by the same injury, pursuing claims with common questions that are central to the resolution of the dispute. If one tracks the development of Rule 23 and focuses on the origins and

${ }^{42}$ Equal Employment Opportunity Restoration Act of 2012, S. 3317, 112th Cong. $\S 2$ (as introduced by Sen. Franken, June 20, 2012) ("The purpose of this Act is to restore employees' ability to challenge, as a group, discriminatory employment practices, including subjective employment practices."). Although it is beyond the scope of this Article to comment on the merits of this legislative proposal, suffice it to say that to the extent the Court constricts access to courts through its interpretation of procedural doctrine, it is no surprise that members of Congress who would prefer to see greater access to courts would attempt to create avenues that facilitate such access, particularly if they view such access as instrumental in promoting policy ends they value, such as antidiscrimination.

${ }^{43}$ A. Benjamin Spencer, The Restrictive Ethos in Civil Procedure, 78 GeO. WaSH. L. REv. 353, 353-54 (2010). 
original understanding of the commonality provision, ${ }^{44}$ however, it is clear that the interpretation of commonality offered by the Dukes majority attempts to resurrect concepts that are distinct and have been long abandoned.

Although Rule 23 is derived largely from the representative action provision in the Federal Equity Rules of 1912, the "common question of law or fact" language derives most directly from the English joinder rule, which was promulgated in the late nineteenth century. Exploring English practice under this rule can thus enlighten one's view of commonality. To see this connection, it is best to work backward. Section A examines the 1938 version of Rule 23 and its American and English antecedents. Section B then turns to the modern version of Rule 23 promulgated in 1966 in light of this history.

\section{A. The Antecedents of Rule 23}

Rule 23 restated and replaced Rule 38 of the Federal Equity Rules of 1912.45 Equity Rule 38, which dealt with "representatives of a class," read as follows: "When the question is one of common or general interest to many persons constituting a class so numerous as to make it impracticable to bring them all before the court, one or more may sue or defend for the whole." 46 Although the 1912 Equity Rule 38 replaced former Equity Rule 48 - which allowed courts to dispense with joining all parties in a suit when they were too numerous to be joined without causing delay and inconvenience - Rule 48 lacked any reference to a question of common interest. ${ }^{47}$ That language appears to have

44 This type of historically focused analysis is typically endorsed by Justice Scalia, at least in the constitutional interpretation context. See, e.g., McDonald v. City of Chicago, 130 S. Ct. 3020, 3057-58 (2010) (Scalia, J., concurring) ("[T]he question to be decided is not whether the historically focused method is a perfect means of restraining aristocratic judicial Constitution-writing; but whether it is the best means available in an imperfect world. . . I think it beyond all serious dispute that it is much less subjective, and intrudes much less upon the democratic process."); Giles v. California, 554 U.S. 353, 358 (2008) (using historical analysis to determine whether a forfeiture-by-wrongdoing exception to the confrontation right existed during the founding era). Historical analysis is appropriate here not to understand the intention behind an ambiguous text, as the text of Rule 23(a)(2) is far from ambiguous, but rather to reveal that the Dukes interpretation is connected to concepts that were contained in separate provisions of predecessors to Rule 23 that were expressly discarded when the Rule was amended in 1966.

${ }^{45}$ FED. R. CIV. P. 23(a) (1938) advisory committee's note ("This is a substantial restatement of Equity Rule 38 (Representatives of Class) as that rule has been construed.").

${ }^{46}$ FED. R. EQ. 38 (1912) (repealed 1938), reprinted in HOPKINS' NEW FEDERAL EQUITY RULES 214 (James Love Hopkins ed., 4th ed. 1924).

${ }^{47}$ See FED. R. EQ. 48 (1842) (repealed 1912), reprinted in HOPKINS' NEW FEDERAL EQUITY RULES, supra note 46, at 104-05 ("Where the parties on either side are very numerous, and cannot, without manifest inconvenience and oppressive delays in the suit, be all brought before it, the Court in its discretion may dispense with making all of them parties, and may proceed in the suit, having sufficient parties before it to represent all the adverse interests of the plaintiffs and the defendants in the suit properly before it."). 
been borrowed from an 1849 amendment to the Field Code by the New York legislature, which added a provision that is nearly identical to what was found in Equity Rule $38 .{ }^{48} \mathrm{In}$ tum, it has been suggested that the Code provision was inspired by Justice Story's discussion of when representative actions would be appropriate, which he indicated would be "[w]here the parties are very numerous ... or where the question is of a general interest, and a few may sue for the benefit of the whole." 49

These numerosity and question of common interest themes of the equity and code rules were carried forward when the 1938 Federal Rules of Civil Procedure were promulgated and Rule 23 was created to address class actions. The original version of Rule $23^{50}$ made several innovations, however. First, in subparagraph (a)(1), the 1938 rule spoke of the enforcement of a "right" that was "joint, or common" as being sufficient for the first of three different kinds

48 The text of the amended Field Code provision read: "[W]hen the question is one of a common or general interest of many persons, or when the parties are very numerous and it may be impracticable to bring them all before the court, one or more may sue or defend for the benefit of the whole." 1849 N.Y. Laws ch. $438 \S 119$. Charles Clark, reporter for the original Federal Rules Advisory Committee, lamented the disjunctive use of "or" here, permitting class treatment when there was numerosity or commonality. See RULES OF CIVIL Procedure for the District Courts of the United States and Proceedings of the INSTITUTE OF FEDERAL RULES 264 (William W. Dawson ed., 1938) [hereinafter Cleveland INSTITUTE PROCEEDINGS].

${ }^{49}$ West v. Randall, 29 F. Cas. 718, 722 (C.C.D.R.I. 1820) (No. 17,424) (emphasis added); see also Joseph StORY, COMMEnTARIES On EQuity Pleadings 97 (Boston, Charles C. Little \& James Brown 1838) (commenting that one of the most common type of cases illustrating an exception to the requirement of actual joinder is "where the question is one of a common or general interest, and one or more sue, or defend for the benefit of the whole"); William Wirt Blume, The "Common Questions" Principle in the Code Provision for Representative Suits, 30 MicH. L. REv. 878, 878-79 (1932) (suggesting the Justice Story connection). Professor Yeazell derides Justice Story's discussion of representative actions in West when he writes that in West, Justice Story "trotted out a parade of incompletely digested and almost completely irrelevant learning about group litigation." STEPHEN C. Yeazell, From Medieval Group Litigation to the Modern Class ACtion 217 (1987).

50 The original Rule 23 read, in pertinent part:

(a) Representation. If persons constituting a class are so numerous as to make it impracticable to bring them all before the court, such of them, one or more, as will fairly insure the adequate representation of all may, on behalf of all, sue or be sued, when the character of the right sought to be enforced for or against the class is

(1) joint, or common, or secondary in the sense that the owner of a primary right refuses to enforce that right and a member of the class thereby becomes entitled to enforce it;

(2) several, and the object of the action is the adjudication of claims which do or may affect specific property involved in the action; or

(3) several, and there is a common question of law or fact affecting the several rights and common relief is sought.

FED. R. Civ. P. 23(a) (1938). 
of class actions, ${ }^{51}$ a category subsequently referred to as a "true" class action..$^{52}$ Second, subsection (a)(2) of the 1938 rule permitted class actions when the right to be enforced was not joint or common but was "several," provided the action concerned specific property ${ }^{53}$ - the "hybrid" class action. ${ }^{54}$ Third, under subsection (a)(3) of the 1938 rule, classes of claimants whose interests were several could also be permitted if there was "a common question of law or fact affecting the several rights and a common relief is sought," 55 a so-called "spurious" class action..$^{56}$ Observe that the 1938 version of Rule 23 moved from one type of commonality found in the equity rule to three, using the term "common"- meaning shared ${ }^{57}$ - on three occasions. The term was first used to refer to a "common" right to be enforced by the class; second, to refer to "common questions of law or fact affecting the several rights" of the class; and third, to refer to "common relief" that is sought by the class. ${ }^{58}$ These references within a single rule are the result of a blending of influences from the representative action and joinder rules of early American codes and English procedure. Each of these influences is disaggregated and reviewed below.

\section{The Precursors of the Common Right Requirement}

Although not the focus of this Article, taking a brief look at the forerunners of the common right requirement advances the goal of understanding the common question test by way of contradistinction. That is, as one comes to understand the distinctive nature and meaning of this trait vis-à-vis the common question standard, any confusion between the two can be thwarted.

The 1938 version of Rule 23(a)(1) permitted class treatment when "the right sought to be enforced for or against the class is [] joint, or common." 59 This type of class was the "true" class and reflected party joinder rules under the codes. The Field Code made joinder compulsory for parties who were "united in interest" and permissive for parties who had an interest in the "subject of the action" or "controversy." 60 The subject of an action was what was at issue in

\footnotetext{
51 Id.

52 FED. R. Civ. P. 23 (1966) advisory committee's note on 1966 amendment to rules (" $[\mathrm{T}]$ he so-called 'true' category was defined as involving 'joint, common, or secondary rights ...."').

${ }^{53}$ FED. R. CIV. P. 23(a)(2) (1938).

${ }^{54}$ FED. R. Civ. P. 23 (1966) advisory committee's note on 1966 amendment to rules (referring to "the 'hybrid' category[] as involving 'several' rights related to 'specific property"').

55 FED. R. Civ. P. 23(a)(3) (1938) (emphasis added).

s6 FED. R. CIV. P. 23 (1966) advisory committee's note on 1966 amendment to rules.

571 The New Century Dictionary 291 (1927) (defining “common" as "[b]elonging equally to or shared alike by two or more or all in question").

${ }^{58}$ Fed. R. Civ. P. 23(a) (1938)

59 FED. R. Civ. P. 23(a)(1) (1938).

60 First Report of the Commissioners on Practice and Pleading $§ 99$ (1848)
} 
the case, such as the premises to be partitioned, ${ }^{61}$ the damages sustained by an injunction, ${ }^{62}$ or the harm caused by a defendant's act. ${ }^{63}$ When each plaintiff was concerned with a particular subject, the requisite connection among them to permit joinder could be found. No such common interest in the subject of an action would be found, however, when the plaintiffs separately suffered harm from the similar conduct of a common defendant on different occasions. ${ }^{64}$ Interestingly, although a common interest in the subject matter of the suit was required for simple party joinder, the standard for permitting a representative action under the codes seemed broader, requiring only a common interest in a question before the court. ${ }^{65}$ As shown below, this broader approach found a

[hereinafter FIELD CODE]; id. \$§ 97-98.

${ }^{61}$ Ripple v. Gilborn, 8 How. Pr. 456, 461 (N.Y. Sup. Ct. 1853) ("The Code directs that all persons having an interest in the subject of the action and in obtaining the relief demanded may (should) be joined as plaintiffs. The subject of this action is the premises sought to be partitioned, and no one pretends to deny but that the plaintiff's wife possesses an inchoate right of dower in said premises." (citation omitted)).

${ }^{62}$ Loomis v. Brown, 16 Barb. 325, 325 (N.Y. Sup. Ct. 1853) ("[W]here an action is brought upon an injunction bond, the subject of the action being the damage sustained by the plaintiffs in consequence of the injunction ... all the obligees may join as plaintiffs ... ." (emphasis omitted)).

${ }^{63}$ Simar v. Canaday, 53 Sickels 298, 306, 1873 WL 5719, at *5 (N.Y. 1873) ("Here both plaintiffs have an interest in the subject of the action; be that subject the property conveyed, or the acts of the defendant and the consequent damage, and both have an interest in obtaining the relief demanded.").

${ }^{64}$ This point is illustrated in Gray v. Rothschild, 1 N.Y.S. 299 (Sup. Ct. 1888), a case involving seven different businesses that sold goods at different times to the defendants as a result of false representations:

The subject of the action is the recovery of the damages sustained by each one of the firms in the sale of their own goods. Each sale was distinct from all the others, and made upon fraudulent representations inducing such sale. There was no concurrent or joint action by the several firms whose members have been joined as plaintiffs in the sales of their respective goods, but each firm proceeded and transacted the business for itself; and for the value or price of its goods, if the facts are truthfully alleged in the complaint, each firm is entitled to a separate and distinct recovery. And no facts are alleged in the case, in any form, which would secure to the plaintiffs joint relief by way of a joint judgment.

Id. at 300 .

651849 N.Y. Laws ch. $438 \S 119$ ("When the question is one of a common or general interest of many persons, or when the parties are very numerous and it may be impracticable to bring them all before the court, one or more may sue or defend for the benefit of the whole."). Professor Blume noted the difference between the two standards found in the joinder and representative action rules under the codes:

[I]t seems clear that these two provisions of the code furnish different tests for determining when persons may join as plaintiffs in an action. The requirement that they have an interest in "the subject" of the action suggests that there must be some one title or thing which is the subject of the action and in which all the plaintiffs must have an interest, while the requirement that they have a common or general interest in "the 
home in the spurious class action of 1938's Rule 23(a)(3), while the tighter commonality of interest in the subject of the suit bears closer resemblance to the original "joint, or common" right provision of the true class action of Rule $23(a)(1) \cdot 66$

In nineteenth-century England, both the representative action rule and the basic joinder rule initially required the same unity of interest in the subject matter of the suit that was reflected in similar provisions in the American codes previously discussed. The English representative action rule, Rule 9 of Order XVI of the English Rules of the Supreme Court, read as follows:

Where there are numerous persons having the same interest in one cause or matter, one or more such persons may sue or be sued, or may be authorized by the Court or a Judge to defend in such cause or matter, on behalf or for the benefit of all persons so interested. ${ }^{67}$

This "same interest" requirement typically was interpreted strictly to preclude claims that were based on rights lacking a "common origin"68 or claims that sought damages as relief. ${ }^{69}$ Thus, even if there was a common source of the plight of multiple plaintiffs, that was not a sufficient connection to permit a representative action. ${ }^{70}$

question" before the court suggests that joinder is allowed where, if separate suits were brought, the same question of law or fact would be involved.

Blume, supra note 49 , at 880 .

${ }^{66}$ Note that these subsection references are to the 1938 rule and its numbering, which differs from that of the current version of Rule 23.

${ }^{67}$ Rules OF THE SuPREME Court (English), 1883, Order XVI, r. 9 (emphasis added). Decades before the promulgation of the English rule, Frederic Calvert had used similar language to theorize on the topic of representative litigation, concluding that "when a large number of persons have a common interest in the entire object of a suit in its nature beneficial to all, one or more of them may sue on behalf of all." FREDERIC CALVERT, A Treatise upon the Law Respecting Parties to Suits IN EQuity *41 (1837). Credit for this reference goes to Professor Yeazell, who expounds on the insight and contribution of Calvert in his important book on the history of class actions. See YEAZELL, supra note 49, at 207-10.

${ }^{68}$ Markt \& Co. v. Knight Steamship Co., [1910] 2 K.B. 1021 (C.A.) 1029 (Vaughan Williams L.J.) (" $[\mathrm{I}] \mathrm{n}$ the present case there is no common origin of the claims of those who shipped goods on board the Knight Commander - the contracts were constituted by the bills of lading, which manifestly might diffier much in their form, and as to the exceptions, and probably would vary somewhat according to the nature of the goods shipped.").

${ }^{69}$ Id. at 1040-41 (Fletcher Moulton L.J.) ("To my mind no representative action can lie where the sole relief sought is damages, because they have to be proved separately in the case of each plaintiff, and therefore the possibility of representation ceases.").

${ }^{70}$ Lord Justice Vaughan Williams, writing in Markt, illustrated this understanding of the "same interest" requirement in rejecting a representative action attempted by multiple shippers whose respective cargoes were lost when a steamship was sunk by a Russian cruiser:

These shippers no doubt have a common wrong in that their goods were lost by the 


\section{The Origin of the "Common Question" Requirement}

This common interest approach of the code joinder practice and English representative action jurisprudence characterized ordinary party joinder practice in England as well, but only up to 1896. Before that point, courts regularly interpreted the English joinder rule, Rule 1 of Order XVI of the English Rules of the Supreme Court, ${ }^{71}$ as requiring parties to be united in their interest in the same cause of action. ${ }^{72}$ For example, in Carter v. Rigby, the plaintiffs, survivors of fifty miners who were drowned in the flooding of a mine, sought to join in a single action against the defendants, the mine owners. ${ }^{73}$ The court, bound by prior precedent interpreting the joinder rule, held that the rule "does not authorize the joinder of the plaintiffs in this action, although the matter which is alleged against the defendants, and which gave rise to all the actions, was the same in each case." 74

In response to this line of cases, however, the Rules of the Supreme Court were amended to reform joinder practice in a manner that created the very common question requirement now found in Rule 23. In 1896, Rule 1 of Order XVI of the English Rules of the Supreme Court was amended to read as follows:

All persons may be joined in one action as plaintiffs, in whom any right to relief in respect of or arising out of the same transaction or series of transactions is alleged to exist, whether jointly, severally, or in the alternative, where if such persons brought separate actions any common question of law or fact would arise; provided that, if upon the application of any defendant it shall appear that such joinder may embarrass or delay the trial of the action, the court or a judge may order separate trials $\ldots{ }^{75}$

The original version of Rule 1, promulgated in 1883, lacked the "transaction" and "common question" language ${ }^{76}$ added by the 1896 amendment."

sinking of the Knight Commander by the Russian warship; but I see no common right, or common purpose, in the case of these shippers . . . A All sorts of facts and all sorts of exceptions may defeat the right of individual shippers. The case of each shipper must to my mind depend upon its own merits.

Id. at 1029-30 (Vaughan Williams L.J.).

${ }^{71}$ RULES OF THE SUPREME COURT (English), 1883, Order XVI, r. 1 ("All persons may be joined as plaintiffs in whom the right to any relief claimed is alleged to exist, whether jointly, severally, or in the altemative.").

72 See Carter v. Rigby \& Co., [1896] 2 Q.B. 113 at 114; Peninsular \& Oriental Steam Navigation Co. v. Tsune Kijima, [1895] A.C. 661 (H.L.) 664 (appeal taken from China and Japan); Smurthwaite v. Hannay, [1894] A.C. 494 (H.L.) 496 (appeal taken from Eng.).

${ }^{73}$ Carter, 2 Q.B. at 113.

74 Id. at 119 (Lord Esher M.R.) (citing Smurthwaite, A.C. at 496).

75 RULES OF THE SUPREME COURT (English), 1896, Order XVI, r. 1 (emphasis added); see also Benning v. Ilford Gas Co., [1907] 2 K.B. 290 at 290 n.l.

76 RUles OF THE SuPreme COURT (English), 1883, Order XVI, r. 1.

77 See John Indermaur, A Manual of the Practice of the Supreme Court of 
According to judges of the English Court of Appeal at the time, the amendment was in response to cases in which joinder was denied, notwithstanding the presence of common questions. ${ }^{78}$ This alteration created a distinction between the common rights connection needed for representative actions and the more relaxed common question standard for simple joinder.

Not too long after this amendment, the court in Markt \& Co. v. Knight Steamship Co. ${ }^{79}$ highlighted this distinction when it faced a circumstance - the loss of respective cargo by independent shippers due to the same sinking of a ship - that failed to satisfy the "same interest" requirement for a representative action but satisfied the common question requirement for simple joinder. ${ }^{80}$ Lord Justice Williams emphasized the difference thusly:

I do not think that the Judicature Act Orders and Rules intended that r. 9 of Order XVI. [(the representative action rule)] should be available whenever those on whose behalf the plaintiff affected to sue could shew that the right to relief arose in respect of or arising out of the same transaction or series of transactions alleged to exist, whether jointly, severally, or in the alternative where, if such persons brought separate actions, any common question of law or fact would arise, such as to allow a joinder of plaintiffs under Order XVI., r. 1 [(the basic joinder rule)]. ${ }^{81}$

Therefore, even though the plaintiffs in Markt suffered from a "common wrong," 82 the common interest needed to permit a representative action was not present, meaning the representative action failed. This made clear the distinction between the same-interest and common question standards, with the former being more stringent than the latter.

The case of Universities of Oxford and Cambridge v. George Gill \& Sons ${ }^{83}$ provides one of the earliest discussions of the new common question concept. At issue in that case was Gill \& Sons' unauthorized publication of texts bearing the Oxford and Cambridge names and arms, confusing consumers and harming the respective plaintiffs. ${ }^{84}$ The question before the court was whether the two plaintiffs could join their separate claims. After finding the transaction test satisfied, the court looked for common questions. ${ }^{85}$ The court explained

JudicAture IN THE King's BenCh AND ChANCERy Divisions 34 (London, Stevens and Haynes, 8th ed. 1901).

${ }^{78}$ Stroud v. Lawson, [1898] 2 Q.B. 44 (C.A.) 49-51 (A.L. Smith L.J.) ("That rule [amending Rule 1, Order XVI] was brought into operation after the decision in Carter $v$. Rigby \& Co. The first of the cases which led to an alteration of the rules on this subject was Smurthwaite v. Hannay.").

${ }^{79}$ [1910] 2 K.B. 1021 (C.A.) 1029.

$80 \mathrm{Id}$. at 1027.

${ }^{81}$ Id. at 1030.

${ }^{82}$ Id. at 1029-30.

${ }^{83}$ [1899] 1 Ch. 55 (Eng.).

${ }^{84}$ Id. at $55-59$.

${ }^{85} \mathrm{Id}$. at 60-61. 
that under the joinder rule, the analysis entailed no more than identifying a factual question the court would need to decide to resolve the claims of both plaintiffs, "where if such persons brought separate actions any common question of law or fact would arise." 86 In other words, if each plaintiff proceeded individually, what legal or factual questions, if any, would arise in both cases? Applying that test, the court found at least two common questions: first, the publication of the books, and second, the effect on consumers of titling the offending books as "The Oxford and Cambridge Edition." 87 The court found that joinder was therefore appropriate. ${ }^{88}$

Understanding this change in English law and the distinct meaning of the common right versus the common question standards is important for our purposes because it is from this 1896 version of the English joinder rule that the common question concept within Rule 23 derives. Recall that Equity Rule 38 used the phrase "question... of common or general interest." 89 The 1938 version of Rule 23(a)(3) adopted the phrase "common question of law or fact." ${ }^{90}$ Indeed, similar common question language appeared in other new Federal Rules as well: Rule 20, the permissive joinder rule; ${ }^{91}$ Rule 24, the rule permitting intervention of parties; ${ }^{92}$ and Rule 42, the rule permitting the consolidation of actions for trial. ${ }^{93}$ This was not by coincidence. Charles Clark, the Reporter for the committee that drafted the 1938 Rules, described the

${ }^{86}$ Id. at 61 (quoting RULES OF THE SụPREME COURT (English), 1896, Order XVI, r. 1).

${ }^{87} \mathrm{Id}$. at 61 .

${ }^{88}$ Id. at 61-62. It is worth noting that under the English joinder rule, courts retained discretion to order separate trials even if common questions of law or fact were present. This discretion was exercised in a manner evocative of the predominance inquiry under Rule 23(b)(3) today:

It is impossible to lay down any rule as to how the discretion of the Court ought to be exercised. Broadly speaking, where claims by or against different parties involve or may involve a common question of law or fact bearing sufficient importance in proportion to the rest of the action to render it desirable that the whole of the matters should be disposed of at the same time the Court will allow the joinder of plaintiffs or defendants....

Payne v. British Time Recorder Co., [1921] 2 K.B. 1 (C.A.) 16 (Scrutton L.J.). As explored below, the Dukes majority's approach to commonality integrates this discretionary concern over the weight of the common question into the meaning of the common question requirement itself rather than leaving it within the realm of the predominance inquiry of today's Rule 23(b)(3).

${ }^{89}$ FED. R. EQ. 38 (1912) (replaced in 1938 by FED. R. CIV. P. 23).

90 FED. R. CIV. P. 23(a)(3) (1938).

91 FED. R. CIV. P. 20(a) (1938).

92 FED. R. CIV. P. 24(b) (1938).

${ }^{93}$ FED. R. CIV. P. 42(a) (1938). The common question language also appears in the Multidistrict Litigation statute, although it is confined to common questions of fact: "When civil actions involving one or more common questions of fact are pending in different districts, such actions may be transferred to any district for coordinated or consolidated pretrial proceedings." 28 U.S.C. $§ 1407$ (a) (2006). 
"spurious class suit" of Rule 23(a)(3) as "really only a kind of joinder"94 and indicated that it was "merely a short cut to cases where joinder is permissive." 95 Looking then to the basic joinder rule, Rule 20, one finds the source of the common question language of Rule 23(a)(3). As the Advisory Committee note expressly states, Rule 20 , in turn, borrowed the "common question" language from the English joinder rule ${ }^{96}$ In discussions surrounding the new joinder rules, Clark indicated that the "common question of law or fact test" - the exact language that appears in Rule 23(a)(3) - came directly from the English rule and he endorsed its breadth. ${ }^{97}$

\section{The Contradistinction Between Common Questions and Common Rights}

As has been shown, the common right and common question concepts have distinct meanings and origins. Knowing this clarifies why the two concepts are distinguished from one another in the 1938 version of Rule 23. Indeed, the three separate uses of the term "common" in the 1938 rule, in light of this history, reflect three different types of commonality, each distinct from the others. That is, a common question is not the same thing as, or subsumed within, a common right. And a common question is not identical to common relief, as both were requirements of being certified as a class under former Rule 23(a)(3).

The decision in Skinner v. Mitchel ${ }^{98}$ - cited by the original Advisory Committee as illustrative of the circumstances under which the common question requirement of Rule 23 would be satisfied - quoted Pomeroy's Equity Jurisprudence to illuminate the distinction between common rights and common questions in the class action context as follows:

" $[\mathrm{N}]$ otwithstanding the positive denials by some American courts, the weight of authority is simply overwhelming that the jurisdiction may and

94 Cleveland Institute Proceedings, supra note 48, at 264.

95 Federal Rules of Civil Procedure: Proceedings of the Institute at WASHINGTON, D.C. AND OF THE SYMPOSIUM AT NEw YoRK City 67 (Edward H. Hammond ed., 1939).

${ }^{96}$ FED. R. CIV. P. 20(a) (1938) advisory committee's note ("The first sentence is derived from English Rules Under the Judicature Act (The Annual Practice, 1937) O. 16, r. 1.”).

97 Cleveland Institute Proceedings, supra note 48, at 260-61 (lamenting the restrictive joinder jurisprudence under the codes and stating that "the wider joinder permitted by the English rules," which was facilitated by the "common question of law or fact test[,]' has been adopted and is stated in these rules"); see also ATLANTA BAR ASS'N, Proceedings of the Atlanta Institute on Federal Rules of Civil Procedure 47-48 (1938) ("[Rule 20] is taken from the English practice ... . We are going to save time if we dispose of one or more questions affecting the whole crowd, whether those questions be of fact or law. By this statement of the rule we also have the advantage of having the authorities from England ....").

98197 P. 569 (Kan. 1921). 
should be exercised, either on behalf of a numerous body of separate claimants against a single party, or on behalf of a single party against such a numerous body, although there is no 'common title,' nor 'community of right' or of 'interest in the subject-matter,' among these individuals, but where there is and because there is merely a community of interest among them in the questions of law and fact involved in the general controversy, or in the kind and form of relief demanded and obtained by or against each individual member of the numerous body. In a majority of the decided cases, this community of interest in the questions at issue and in the kind of relief sought has originated from the fact that the separate claims of all the individuals composing the body arose by means of the same unauthorized, unlawful, or illegal act or proceeding. Even this external feature of unity, however, has not always existed, and is not deemed essential. Courts of the highest standing and ability have repeatedly interfered and exercised this jurisdiction, where the individual claims were not only legally separate, but were separate in time, and each arose from an entirely separate and distinct transaction, simply because there was a community of interest among all the claimants in the question at issue and in the remedy." 99

Two things are worth observing here. First, Pomeroy counterposes "community of right" to the "mere[] . . community of interest among them in the questions of law and fact involved in the general controversy," affirming the distinctiveness of the two concepts. ${ }^{100}$ Second, classes lacking such a "community of right" - or, to use the language of the 1938 rule, a "right" that is "joint, or common" - are approved if there are two other kinds commonalities. Specifically, the last line of the quote - endorsing class treatment when "each [claim] arose from an entirely separate and distinct transaction, simply because there was a community of interest among all the claimants in the question at issue and in the remedy" - reflects precisely the type of class authorized by subparagraph (a)(3) in the 1938 version of Rule 23. That clause permitted class actions when the rights to be enforced are "several, and there is a common question of law or fact affecting the several rights and common relief is sought." 101

All of this is to say that the 1938 rule speaks of three separate kinds of commonality - common rights, common questions, and common relief which were not interchangeable concepts but rather focused attention on three very different traits that could describe a collective of claimants. The sameinterest concept discussed above is the ancestor of the common rights component of the 1938 version of Rule 23. As explained by the Advisory

99 Id. at 571 (emphasis added) (quoting 1 John Norton PoMERoY, A TrEatise ON EQUITY JURISPRUDENCE AS ADMINISTERED IN THE UNITED STATES OF AMERICA § 269 (4th ed. 1918)).

$100 \mathrm{Id}$.

101 FED. R. CIV. P. 23(a)(3) (1938). 
Committee note to the original rule, ${ }^{102}$ common rights were exemplified by actions by policyholders of a common issuer of the policies, ${ }^{103}$ or in creditors' suits. ${ }^{104}$ The meaning of relief is self-explanatory, simply referring to the remedy that each class member seeks. ${ }^{105}$ However, "common relief" was not treated as joint relief given the express context in which the term was used in the 1938 rule: the enforcement of several rights that were not interdependent. Rather, common relief was read to mean relief emanating from the same source. ${ }^{106}$

Common questions are something different from common rights or common relief. Legal or factual questions are issues presented to a court whose resolution bears on the adjudication of the claims presented. ${ }^{107}$ The modifier "common" simply means that those questions are shared across the collective claims. ${ }^{108}$ The formulation of the English joinder rule aptly stated how one might determine whether this kind of commonality exists: "[I]f such persons brought separate actions any common question of law or fact would arise...."109 That is, one can take the following three-step approach to determining whether common questions exist among the claims: (1) assume

102 FED. R. CIV. P. 23 (1938) advisory committee's note (providing cases illustrating commonality, such as "an action to enforce rights held in common by policyholders against the corporate issuer of the policies" and actions "dealing with the right held in common by creditors to enforce the statutory liability of stockholders").

103 See Hiram H. Lesar, Class Suits and the Federal Rules, 22 MinN. L. REv. 34, 41 (1937) ("Where the right is given to all the creditors, and not to each individual creditor, and the statute is said to contemplate a fund for the common benefit, the right may be classed as common.").

104 Blume, supra note 49, at 880 ("When the object of a creditors' suit is to reach, establish and administer assets in the hands of a trustee who holds them for the benefit of all the creditors, the suit must be by all the creditors or by one or more for the benefit of all." (citation omitted)).

105 Black's LAW Dictionary 1404 (9th ed. 2009) (defining relief as a "redress or benefit ... that a party asks of a court").

106 Kainz v. Anheuser-Busch, Inc., 194 F.2d 737, 743 (7th Cir. 1952) (“'Obviously, the phrase 'common relief,' as used in the rule, was not intended to mean joint relief, for the expressed purpose is to permit joinder of parties who have several or separable causes of action. Hence to say that 'common' means 'joint' is to defeat the very purpose of the rule. 'Common relief' for persons having separate causes of action who may recover only several judgments, it seems to us, must mean, in order to give life to the purpose of the rule, relief emanating from the same original source ....").

107 BLACK'S LAW DiCTIONARY, supra note 105, at 1366 (defining question as an "issue in controversy; a matter to be determined").

108 See Wal-Mart Stores, Inc. v. Dukes, 131 S. Ct. 2541, 2562 (2011) (Ginsburg, J., concurring in part and dissenting in part) ("Thus, a 'question' 'common to the class' must be a dispute, either of fact or of law, the resolution of which will advance the determination of the class members' claims.").

109 Rules of The Supreme Court (English), 1896, Order XVI, r. 1. 
each plaintiff proceeds separately; (2) identify all legal and factual questions that would arise in the process of adjudicating each claim; and (3) determine whether there is a question that would recur in each action. ${ }^{110}$

These distinctions between the three commonalities of the 1938 rule are significant for our consideration of the Dukes interpretation of the contemporary common question requirement because they reveal the illegitimacy of the majority's construction of that provision. The majority's effort to imbue Rule 23's common question concept with a requirement that class members share a common right or injury or that they seek common relief unites concepts that the above discussion shows were meant to stand apart. We will return to this point after completing our genealogy of the commonality requirement with a discussion of the contemporary version of Rule 23 .

\section{B. The Modern Version of Rule 23}

What became of these three types of commonality - common rights, common questions, and common relief - when Rule 23 was overhauled in 1966 ? In short, the amended version of Rule 23 abandoned two of the three, at least nominally, preserving only the reference to common questions of law or fact. ${ }^{111}$ The question is what to make of this development. The Advisory Committee was explicit in explaining its excision of the "joint, or common" right requirement: 'In practice the terms 'joint,' 'common,' etc., which were used as the basis of the Rule 23 classification proved obscure and uncertain." 12 The Advisory Committee buttressed this assertion with extensive citations to cases and commentary. ${ }^{113}$ The amended Rule 23 does not retain the joint or common right requirement in any part of the rule. ${ }^{114}$

110 See, e.g., Payne v. British Time Recorder Co., [1921] 2 K.B. 1 (C.A.) 16-17 (Scrutton L.J.) (Eng.) ("There is then the question common to both cases: Are the goods according to this sample or not? If the two present defendants were not joined the result would be that there would be two actions which would be set down to be heard together. An application would then be made to the judge at the trial not to dispose of one of them until he had heard the other, and the judge would endeavour to get in the evidence in both actions and exactly the same result would follow as if the joinder of the two defendants were allowed."); see also Saltzman v. Pella Corp., 257 F.R.D. 471, 478 (N.D. Ill. 2009) ("The determinative question is whether the same issues would necessarily be re-litigated over and over again if plaintiffs were required to bring separate actions." (citing Joseph v. Gen. Motors Corp., 109 F.R.D. 635, 642 (D. Colo. 1986))).

111 FED. R. CIV. P. 23(a) (1966) (“One or more members of a class may sue or be sued as representative parties on behalf of all only if ... (2) there are questions of law or fact common to the class ....").

112 FED. R. CIV. P. 23 (1966) advisory committee's note.

113 Id. (citing law review articles and cases).

114 The closest the modem Rule 23 gets to those concepts is with its requirement that the class representative's claims be typical of the class claims. FED. R. CIV. P. 23(a)(3). This should not, however, be read as a requirement that the class representative and class members seek to enforce "joint, or common" rights. FED. R. CIV. P. 23(a)(3) (1938). 
The fate of the "common relief" requirement in the 1966 amendment to Rule 23 is more nuanced. Although the language disappeared with the amendment, the idea of common versus individualized relief remained relevant, at times, to the class certification analysis under the newly developed predominance requirement, as well as when injunctive relief was being sought. ${ }^{115}$ Taking the latter circumstance first, the 1966 rule endorsed class treatment when "injunctive relief or corresponding declaratory relief with respect to the class as a whole" was appropriate. ${ }^{116}$ This is certainly a type of "common relief" even though those words are not expressly used. Regarding the connection with predominance, as individual class members move toward seeking distinctive, individualized relief, some courts have treated the propriety of class certification under those circumstances as a proper subject of the predominance inquiry. ${ }^{117}$ The Advisory Committee Notes to the rule, however, indicate that such an approach is improper. ${ }^{118}$ Regardless of how courts treat the issue of individualized relief, it remains that with respect to the prerequisites for class certification under the modem rule, seeking common

Typicality has been interpreted to mean that the class representative's claim "is fairly encompassed" within the claims of class members. Gen. Tel. Co. of the Nw. v. EEOC, 446 U.S. 318,330 (1980) ("The typicality requirement is said to limit the class claims to those fairly encompassed by the named plaintiff's claims."). Certainly, were plaintiffs enforcing a joint right, the typicality standard would be satisfied. Given the Advisory Committee's express rejection of the concept of joint or common rights as useful in determining the propriety of a class action, however, reading such concepts into the typicality requirement would be inappropriate. Further, as a matter of simple English, typical was not synonymous with joint, common, or "the same" but rather meant, "exhibiting the essential characteristics of a group." WeBSTER's New INTERNATIONAL Dictionary 2751 (2d ed. 1960). In sum, abandoning the common right language, disparaging it in the accompanying note, and then introducing a new word of distinct English meaning taken together disqualified the typicality-as-common-right interpretation as a legitimate reading of the rule.

115 35A C.J.S. Federal Civil Procedure $\S 93$ (2003 \& Supp. 2012) ("[T]he pursuit of compensatory damages counsels against a finding of the predominance of questions common to class members over questions affecting only individual members.").

116 FED. R. CIV. P. 23(b)(2) (1966).

117 See, e.g., Robertson v. N. Am. Van Lines, Inc., No. C-03-2397, 2004 WL 5026265, at *4 (N.D. Cal. Apr. 19, 2004) ("Each member of the class will have a different measure of damages based on a multitude of factors surrounding their particular move. These individual questions will dominate trial of this action, both in terms of time and significance, which demonstrates that this proposed class is not sufficiently cohesive to warrant adjudication by representation.").

118 FED. R. CIV. P. 23 (1966) advisory committee's note ("[A] fraud perpetrated on numerous persons by the use of similar misrepresentations may be an appealing situation for a class action, and it may remain so despite the need, if liability is found, for separate determination of the damages suffered by individuals within the class."); see also 2 ALBA Conte \& Herbert B. Newberg, Newberg On Class Actions $\S 4: 26$ (4th ed. 2002) (citing cases in support of the proposition that predominance is not undermined by the need for individualized damage determinations). 
relief is no longer a requirement save for the injunctive relief class under Rule 23(b)(2).

Of the three commonalities found within the 1938 version of the rule, then, the sole survivor is the common question concept, found today within Rule 23(a)(2)'s requirement that "there are questions of law or fact common to the class." 19 As has been shown, this language covers different ground than the abjured common right and common relief requirements of the 1938 rule. As also established above, the common question requirement found in Rule 23(a)(2) is no more than a simple requirement that there be issues for the court's determination that would arise in the adjudication of each class member's claims were they litigated separately. How did the Court stray from these basic principles in expounding on the meaning of commonality in Dukes? It is that question to which we now tum.

\section{DUKES AND THE DEVELOPMENT OF HEIGHTENED COMMONALITY}

Prior to Dukes, federal courts had embraced a view of commonality consistent with the meaning described above. The requirement was seen as easy to satisfy, with the necessary showing being characterized as "minimal" 120 and permissively construed. ${ }^{121}$ This is not to say that commonality was regarded as no requirement at all; to the contrary, the common questions had to pertain to an issue or issues that would "advance the litigation." 122 This made sense, as the definition of a legal or factual question is "an issue in controversy; a matter to be determined." 123 Obviously, the common question has to be germane to the resolution of the class claims rather than extraneous; otherwise, the question would not be a real one in the case. But the Dukes majority went further than this, yielding an unrecognizable conception of commonality that improperly blends disparate components of contemporary and predecessor rules governing joinder and representative actions.

119 FED. R. Civ.. P. 23(a)(2).

120 Hanlon v. Chrysler Corp., 150 F.3d 1011, 1020 (9th Cir. 1998); Lewis Tree Serv., Inc. v. Lucent Techs., Inc., 211 F.R.D. 228, 231-32 (S.D.N.Y. 2002) ("[T]he commonality requirement of Rule 23(a)(2) is usually a minimal burden for a party to shoulder.").

${ }^{121}$ In re New Motor Vehicles Canadian Exp. Antitrust Litig., 522 F.3d 6, 19 (1st Cir. 2008) ("Rule 23(a)'s requirement of commonality is a low bar, and courts have generally given it a 'permissive application."' (quoting 7A CharLes AlaN Wright, ARTHUR R. Miller \& Mary Kay Kane, Federal Practice and Procedure $§ 1763$ (3d ed. 2005))); Hanlon, 150 F.3d at 1019 ("Rule 23(a)(2) has been construed permissively.").

122 Sprague v. Gen. Motors Corp., 133 F.3d 388, 397 (6th Cir. 1998) (en banc) ("It is not every common question that will suffice, however; at a sufficiently abstract level of generalization, almost any set of claims can be said to display commonality. What we are looking for is a common issue the resolution of which will advance the litigation.").

123 BLACK'S LAW DiCTIONARY, supra note 105, at 1366 (emphasis added). 
The Dukes Court set forth a new standard for commonality with three requirements. First, claimants must "'have suffered the same injury." 124 Second, the common question must be "central to the validity of each one of the claims."125 Third, the common question must be one whose determination will resolve a central issue "in one stroke" by "generat[ing] common answers apt to drive the resolution of the litigation." 126 This Article will refer to these three requirements as the same injury, centrality, and efficiency requirements. ${ }^{127}$ This Article will proceed with a discussion of how each of these aspects of heightened commonality is problematic.

\section{A. The Same Injury Requirement}

The Dukes majority was wrong to infuse commonality with a same injury requirement for several reasons. The first is textual. Justice Scalia, who often touts his fealty to the written text of enacted rules and statutes, ${ }^{128}$ displays none of that discipline in Dukes. The language of Rule 23(a) - that "there are questions of law or fact common to the class" - expresses no need for class members to have suffered the "same injury." Although a common injury shared by the claimants would meet the requirement that there be questions common to the class, Rule 23 nowhere mentions such a circumstance as one of its prerequisites or otherwise indicates that such an injury is the sine qua non of commonality. And according to the Court, it is the text of the rule that was meant to govern, notwithstanding the Court's superintending role over the rules-amendment process. ${ }^{129}$ Other members of the Dukes majority have

124 Wal-Mart Stores, Inc. v. Dukes, 131 S. Ct. 2541, 2551 (2011) (quoting Gen. Tel. Co. of the Sw. v. Falcon, 457 U.S. 147, 157 (1982)).

125 Id. (emphasis added).

126 Id.

127 Professor Effron also uses the term centrality in this context. Robin J. Effron, The Shadow Rules of Joinder, 100 GEO. L.J. 750, 802 (2012). She uses the term "resolvability" for the aspects of the majority's interpretation that this Article labels with the term "efficiency." Id.

128 See, e.g., Scalia, supra note 1, at 22 ("The text is the law, and it is the text that must be observed.").

129 Amchem Prods., Inc. v. Windsor, 521 U.S. 591, 620 (1997) (“And, of overriding importance, courts must be mindful that the Rule as now composed sets the requirements they are bound to enforce. Federal Rules take effect after an extensive deliberative process involving many reviewers: a Rules Advisory Committee, public commenters, the Judicial Conference, this Court, the Congress. The text of a rule thus proposed and reviewed limits judicial inventiveness. Courts are not free to amend a rule outside the process Congress ordered . . . ." (citations omitted)); see also Swierkiewicz v. Sorema, 534 U.S. 506, 514-15 (2002) ("Whatever the practical merits of this argument, the Federal Rules do not contain a heightened pleading standard for employment discrimination suits. A requirement of greater specificity for particular claims is a result that 'must be obtained by the process of amending the Federal Rules, and not by judicial interpretation."' (quoting Leatherman v. Tarrant Cnty. Narcotics Intelligence \& Coordination Unit, 507 U.S. 163, 168 (1993))). 
similarly articulated a belief in adhering to the language of statutory texts when interpreting them; ${ }^{130}$ yet that conviction was not in evidence in Dukes.

The absence of such language relates to the second problem with the majority's interpretation of commonality: the history of Rule 23 and its antecedents discussed above reveal that a "same injury" test is a distinct requisite that was eschewed by the drafters of the present rule. ${ }^{131}$ The 1938 version of Rule 23 permitted classes that sought to enforce "joint, or common" rights. ${ }^{132}$ Under the codes, joinder was proper when parties were "united in interest" or if they shared "an interest in the subject of the action" or "controversy," 133 with representative actions being permissible when "the question is one of a common or general interest."134 The English representative action rule allowed a plaintiff to represent absent claimants when they had "the same interest in one cause or matter." 135 The Dukes majority's "same injury" requirement echoes these provisions. Injury refers to "the violation of another's legal right"; ${ }^{136}$ requiring all class members to have suffered the same legalrights violation is tantamount to requiring that "the right sought to be enforced for ... the class is . . common," the very requirement that failed to survive the 1966 revision of Rule $23 .{ }^{137}$ Similarly, the "same injury" gloss on commonality

130 See, e.g., Harbison v. Bell, 556 U.S. 180, $198-99$ (2009) (Thomas, J., concurring) ("This Court's interpretive function requires it to identify and give effect to the best reading of the words in the provision at issue. Even if the proper interpretation of a statute upholds a 'very bad policy,' it 'is not within our province to second-guess' the 'wisdom of Congress' action' . . . ' 'Our task is to apply the text, not to improve upon it."' (citations omitted) (quoting Eldred v. Ashcroft, 537 U. S. 186, 222 (2003); Pavelic \& LeFlore v. Marvel Entm't Grp., 493 U.S. 120, 126 (1989))); id. at 196 (Roberts, C.J., concurring) ("I entirely agree with JUSTICE THOMAS that 'Congress' intent is found in the words it has chosen to use,' and that '[o]ur task is to apply the text, not to improve upon it,' even if that produces 'very bad policy."' (quoting id. at 198-99 (Thomas, J., concurring))); Arlington Cent. Sch. Dist. Bd. of Educ. v. Murphy, 548 U.S. 291, 296 (2006) (Alito, J.) ("We have 'stated time and again that courts must presume that a legislature says in a statute what it means and means in a statute what it says there.' When the statutory 'language is plain, the sole function of the courts - at least where the disposition required by the text is not absurd - is to enforce it according to its terms."' (citations omitted) (quoting Conn. Nat'l Bank v. Germain, 503 U.S. 249, 253-54 (1992); Hartford Underwriters Ins. Co. v. Union Planters Bank, N.A., 530 U.S. 1, $6(2000)))$.

${ }^{131}$ See supra Part I. Note, however, that reference to the history of the rule is unnecessary to derive its meaning since its language is plain and clear. Rather, the history is used to reveal the illegitimacy of Justice Scalia's interpretation of commonality in Dukes.

132 FED. R. Civ. P. 23(a)(1) (1938).

133 FIELD CODE, supra note 60, $§ 99 ;$ id. $\S \S 97,98$.

1341849 N.Y. Laws ch. $438 \S 119$. For a discussion of joinder rules under the procedural codes of the Nineteenth Century, see supra text accompanying notes 61-90.

135 Rules of The Supreme Court (English), 1896, Order XVI, r. 9.

136 BLACK's LAW DiCTIONARY, supra note 105, at 856.

137 FED. R. Civ. P. 23(a)(1) (1938). 
seems close kin to the "the same interest" requirement of the codes and English practice, ${ }^{138}$ the very road not taken, as it were, when our contemporary Rule 23 was drafted. ${ }^{139}$ Certainly the common question concept, existing as it did as an alternative to the common right requirement within the original Rule 23, or in contrast to the same-interest requirement of English representative actions, cannot - consistent with the historical uses of these various terms - be properly treated as being now imbued with the very attributes of its former rivals to which it was originally counterposed.

From where does Justice Scalia derive his "same injury" reading of commonality, if not the text or history of the provision? In Dukes, Justice Scalia twice declares that Rule 23(a) imposes a "same injury" requirement: first when he writes, "[A] class representative must be part of the class and 'possess the same interest and suffer the same injury' as the class members,"140 and again when he states, "Commonality requires the plaintiff to demonstrate that the class members "have suffered the same injury." 141 Both of these statements ultimately originate from Schlesinger $v$. Reservists Committee to Stop the War, ${ }^{142}$ which was an action challenging the military reserve membership of Members of Congress as a violation of the Incompatibility Clause of the U.S. Constitution. ${ }^{143}$ The key issue before the Court was whether the Reservists Committee, which was attempting to bring this action on behalf of four different classes of people, had Article III standing either as citizens or taxpayers. ${ }^{144}$ Taking up the issue of citizen standing, the Court made the following statement:

138 Indeed, Justice Scalia uses the same-interest language at the outset of his opinion in Dukes: "[A] class representative must be part of the class and "possess the same interest and suffer the same injury' as the class members." Wal-Mart Stores, Inc. v. Dukes, $131 \mathrm{~S}$. Ct. 2541, 2550 (2011) (quoting E. Tex. Motor Freight Sys., Inc. v. Rodriguez, 431 U.S. 395, 403 (1977)).

139 See supra notes 63-92. Charles Clark and the Advisory Committee's explicit references to the English joinder rule rather than the English representative action rules as the progenitor of the "common question" language in the Federal Rules of Civil Procedure, coupled with the rejection of the joinder language from the codes, can be interpreted as testament to the deliberateness of the renunciation of the same interest standard. See FED. R. CIV. P. 23 (1938) advisory committee's notes.

140 Dukes, 131 S. Ct. at 2550 (quoting Motor Freight, 431 U.S. at 403).

141 Id. at 2551 (quoting Gen. Tel. Co. of the Sw. v. Falcon, 457 U.S. 147, 156, 157 (1982)).

142418 U.S. 208 (1974).

143 Id. at 210-11. The Incompatibility Clause refers to Article 1, section 6, clause 2 of the U.S. Constitution: "No Senator or Representative shall, during the Time for which he was elected, be appointed to any civil Office under the Authority of the United States, which shall have been created, or the Emoluments whereof shall have been encreased during such time; and no Person holding any Office under the United States, shall be a Member of either House during his Continuance in Office." U.S. CONST., art. I, $\S 6, \mathrm{cl} .2$.

144 Schlesinger, 418 U.S. at at 215-16. In addition to their status as citizens and 
To have standing to sue as a class representative it is essential that a plaintiff must be a part of that class, that is, he must possess the same interest and suffer the same injury shared by all members of the class he represents. ${ }^{145}$

The Court ultimately concluded that the Committee lacked citizen standing because the only interest alleged was a generalized interest in constitutional govemance, an interest that was too abstract to serve as the predicate for standing. ${ }^{146}$ What is important to observe for our purposes, however, is that Schlesinger and the quoted language from the decision were about standing; the case had nothing to do with Rule 23 or the commonality requirement.

In subsequent cases the Court has repeated this language beyond the standing context, each time, as in the game of telephone, morphing it into something unmoored from its original meaning. In East Texas Motor Freight System, Inc. v. Rodriguez, ${ }^{147}$ the Court used Schlesinger's same injury language to declare class representatives ineligible to represent the class due to their admission that they had not suffered any injury. ${ }^{148}$ That fact certainly undermined their standing, although the Court did not explicitly couch the concem in those terms. Rather, the Court cited to a string of cases that did explicitly couch the defect in terms of standing and justiciability. ${ }^{149}$

taxpayers, the Committee attempted to base their standing on their status as military officers and as opponents of the Vietnam War. Id. at 216. Because the district court rejected the latter two bases, and the Committee did not challenge that ruling as error, those categories were not before the Supreme Court. Id.

145 Id. at 216 (emphasis added) (citing Ind. Emp’t Sec. Div. v. Burney, 409 U.S. 540 (1973); Bailey v. Patterson, 369 U.S. 31 (1962)).

$146 I d$. at 220 (" $[\mathrm{S}]$ tanding to sue may not be predicated upon an interest of the kind alleged here which is held in common by all members of the public, because of the necessarily abstract nature of the injury all citizens share.").

147431 U.S. 395 (1977).

148 Id. at 403-04 ("[T]hese [named] plaintiffs lacked the qualifications to be hired as line drivers. Thus, they could have suffiered no injury as a result of the alleged discriminatory practices, and they were, therefore simply not eligible to represent a class of persons who did allegedly suffer injury.").

149 Id. at 403; see also Kremens v. Bartley, 431 U.S. 119, $131 \mathrm{n} .12$ (1977) ("These fragmented subclasses are represented by named plaintiffs whose constitutional claims are moot . . . ."); Sosna v. Iowa, 419 U.S. 393, 403 (1975); Rosario v. Rockefeller, 410 U.S. 752,759 n.9 (1973) ("The petitioners, however, lack standing to raise these contentions."); Hall v. Beals, 396 U.S. 45, 49 (1969) ("[N]othing in the Colorado legislative scheme as now written adversely affects . . . their present interests . . . . [A]ppellants "cannot represent a class of [which] they are not a part."' (quoting Bailey v. Patterson, 369 U.S. 31, 32-33 (1962))); Bailey, 369 U.S. at 31-32 ("Appellants lack standing to enjoin criminal prosecutions under Mississippi's breach-of--peace statutes, since they do not allege that they have been prosecuted or threatened with prosecution under them."). 
By the time this same injury language was repeated in General Telephone Co. of the Southwest v. Falcon, ${ }^{150}$ it was divorced from any reference, explicit or implicit, to Article III justiciability concerns. Rather, sharing the "same injury" was offered first as a freestanding requirement for determining the propriety of a class representative and then as being a trait that demonstrated commonality and typicality. ${ }^{151}$ The Falcon Court wrote: "We have repeatedly held that "a class representative must be part of the class and "possess the same interest and suffer the same injury" as the class members." 152 As just described, however, this requirement was drawn from cases addressing standing, not commonality. Then, the Falcon Court added the following:

Conceptually, there is a wide gap between (a) an individual's claim that he has been denied a promotion on discriminatory grounds, and his otherwise unsupported allegation that the company has a policy of discrimination, and (b) the existence of a class of persons who have suffered the same injury as that individual, such that the individual's claim and the class claims will share common questions of law or fact and that the individual's claim will be typical of the class claims. ${ }^{153}$

It is this formulation that Justice Scalia quoted in Dukes when he wrote, "Commonality requires the plaintiff to demonstrate that the class members "have suffered the same injury." 154 But that is not what the Falcon quote says. Although one can read into this language an equation of commonality with suffering from a common injury, it is better read to indicate that when a class has suffered a common injury, the claims will share common questions of law or fact. In other words, a class comprised of members who have suffered a common injury is sufficient but not necessary to satisfy commonality.

Further, the Court in Falcon was expressly concerned with the unity between the class representative's claim and the claims of absent class members, leading it to blend the commonality and typicality analysis ${ }^{155}$ and explaining its comparisons between "the individual's claim and the class claims" in the excerpt above. ${ }^{156}$ As a result, the shadow of the typicality concern permitted the freestanding commonality requirement to be subsumed and enlarged simultaneously: the Falcon Court treated commonality as if it

150457 U.S. 147, 156-57 (1982).

151 Id. at 156.

152 Id. (quoting Motor Freight, 431 U.S. at 403 (quoting Schlesinger v. Reservists Comm. to Stop the War, 418 U.S. 208, 216 (1974)))).

153 Id. at 157.

154 Wal-Mart Stores, Inc. v. Dukes, 131 S. Ct. 2541, 2551 (2011) (quoting Falcon, 457 U.S. at 157).

155 Falcon, 457 U.S. at 157 n.13 ("The commonality and typicality requirements of Rule 23(a) tend to merge.").

156 Iid. at 157. 
were merely instrumental to determining typicality, ${ }^{157}$ while also offering the language Justice Scalia subsequently used to expand the meaning of commonality to require sufferance of the same injury. 158 That Falcon was about typicality - and not about pronouncing what would have been a radical alteration of the commonality standard - is borne out by its subsequent effects on lower court decisions. Lower courts in the wake of Falcon did not shift their understanding of commonality but rather took Falcon principally as a statement about typicality and the necessary connection that must exist between the claims of class representatives and their respective classes. ${ }^{159}$ And prior to Dukes, the Supreme Court cited Falcon for its statement on Rule 23(a)(4)'s adequacy-of-representation requirement, which it stated "tends to merge with the commonality and typicality criteria of Rule 23(a)."160 Otherwise, the Court gave no indication that Falcon had redefined the traditional understanding of commonality.

Ultimately, the "same injury" requirement spun by Justice Scalia is a fabrication that imbues commonality with long-abandoned and eschewed attributes. At best, such attributes might have been requisites of forming a "true" class under former Rule 23(a)(1), or at worst they reflect an attempt to align American class action standards with those for representative actions in England. ${ }^{161}$ In any event, interpreting commonality to require the same injury is an unsupportable move that the Court should reverse.

157 Id. at 158-59 ("Without any specific presentation identifying the questions of law or fact that were common to the claims of respondent and of the members of the class he sought to represent, it was error for the District Court to presume that respondent's claim was typical of other claims against petitioner . ...").

158 Id. at 157.

159 See, e.g., Wakefield v. Monsanto Co., 120 F.R.D. 112, 116 (E.D. Mo. 1988) ("[C]onsistent with the Supreme Court's opinion in Falcon, the typicality requirement is not always satisfied by suits alleging broad-based racial discrimination. Relevant factors which a court may consider in determining whether a sufficient community of interests exists to make plaintiff's claim typical of the class he or she seeks to represent include a comparison between (i) plaintiff's employment situation and that of the prospective class members, (ii) the circumstances surrounding plaintiff's grievance and those surrounding the prospective class members' grievances, and (iii) the relief sought by plaintiff and that sought by the class.").

160 Amchem Prods., Inc. v. Windsor, 521 U.S. 591, 626 n.20 (1997) (internal quotation marks omitted) (quoting Falcon, 457 U.S. at 157 n.13). Interestingly, in the context of its discussion of adequacy of representation, the Court trotted out the same quote from Schlesinger highlighted in Dukes: "[A] class representative must be part of the class and 'possess the same interest and suffer the same injury' as the class members." Id. at 625-26 (quoting E. Tex. Motor Freight Sys., Inc. v. Rodriguez, 431 U.S. 395, 403 (1977) (quoting Schlesinger v. Reservists Comm. to Stop the War, 418 U.S. 208, 216 (1974))). It appears that this language is quite useful and versatile, as it can be referenced to give meaning to several of the distinct prerequisites found in Rule 23(a).

${ }^{161}$ Under Rule 19.6 of the English Civil Procedure Rules, representative actions are 


\section{B. The Centrality Requirement}

The other two components of heightened commonality, centrality and efficiency, are related to one another and are equally beyond the scope of what Rule 23(a)(2)'s common question requirement contemplates. Centrality is simply a kind of predominance by another name. The core and most important issues in a case, the central issues, by definition "predominate over" less important issues peripheral to the claims at hand. ${ }^{162}$ Thus, by redefining commonality in a way that can only be satisfied when the shared questions are central to the litigation, the Dukes majority, as Justice Ginsburg noted, was quite transparently importing the predominance criterion from Rule 23(b)(3) into the common question analysis. ${ }^{163}$ In addition to Justice Ginsburg's critique in the dissenting portions of her opinion in Dukes, Professor Robin Effron has already quite ably addressed this phenomenon, which she refers to as "implied predominance," 164 both in Dukes and beyond. ${ }^{165}$ I do not repeat their analyses here but only add an observation.

The Court's transmogrification of commonality into centrality (née predominance) is a more objectionable adulteration of the "common question" concept than was the alchemy that produced the same injury requirement.

appropriate "[w]here more than one person has the same interest in a claim." CIv. P. R. 19.6 (2010) (Eng.).

162 See CONTE \& NeWBERG, supra note $118, \S 4: 25$ (expounding on the predominance requirement of Rule $23(\mathrm{~b})(3)$ and stating that "[a] single common issue may be the overriding one in the litigation, despite the fact that the suit also entails numerous remaining individual questions").

163 See Wal-Mart Stores, Inc. v. Dukes, 131 S. Ct. 2541, 2562 (2011) (Ginsburg, J., concurring in part and dissenting in part) ("In so ruling, the Court imports into the Rule 23(a) determination concerns properly addressed in a Rule 23(b)(3) assessment.").

164 Effron, supra note 127, at 799. I acknowledge Professor Effron's view that "implied predominance" and centrality can be distinguished. See id. She describes the former as concerning the relationship between the common and individual issues, and the latter as dealing with the relationship between the issue and the litigation. See id. Although predominance can be a mere numbers game - meaning common issues can predominate if they outnumber the individual issues, see, e.g., In re Visa Check/MasterMoney Antitrust Litig., 280 F.3d 124, 140 (2d Cir. 2001) (finding predominance because common issues outnumbered individual issues) - this Article takes the position that the concepts can often be inextricably intertwined. When undertaking a predominance analysis, a relevant comparison between common and individual issues is their relative degrees of significance to the claims before the court, more so than the mere number of issues of each kind. See CONTE \& NEWBERG, supra note $118, \S 4: 25$ ("A single common issue may be the overriding one in the litigation, despite the fact that the suit also entails numerous remaining individual questions.").

165 Professor Effron discusses implied predominance in ordinary joinder contexts as well as the class action context of Dukes, chronicling how some lower courts before Dukes were wont to "read a predominance requirement into the definition of a common question of law or fact." See Effron, supra note 127, at 789-804. 
Justice Scalia "relied" heavily on an article by the late Professor Richard Nagareda, Class Certification in the Age of Aggregate Proof. ${ }^{166}$ But in Justice Scalia's hands, Nagareda's actual argument was unrecognizable. According to Justice Scalia, Professor Nagareda was dismissive of the notion that the mere presence of common questions was sufficient to warrant class treatment, because "“[a]ny competently crafted class complaint literally raises common "questions."”"167 Justice Scalia further buttressed the Court's centrality thesis by adopting the following quote from Professor Nagareda:

"What matters to class certification ... is not the raising of common 'questions' - even in droves - but, rather the capacity of a classwide proceeding to generate common answers apt to drive the resolution of the litigation. Dissimilarities within the proposed class are what have the potential to impede the generation of common answers."168

The problem with Justice Scalia's application of Professor Nagareda's words is that these words had absolutely nothing to do with the common question requirement of Rule 23(a)(2). Rather, Professor Nagareda was speaking of the predominance requirement of Rule 23(b)(3) and how analysis thereunder should focus on dissimilarities among class claims.

One can see this from the following fuller excerpt from Professor Nagareda's article:

By its terms, Rule 23 speaks of common "questions" that "predominate" over individual ones....

The formulation of Rule 23 in terms of predominant common "questions" and generally applicable misconduct obscures the crucial line between dissimilarity and similarity within the class. The existence of common "questions" does not form the crux of the class certification inquiry, at least not literally, or else the first-generation case law would have been correct to regard the bare allegations of the class complaint as dispositive on the certification question. Any competently crafted class complaint literally raises common "questions." What matters to class certification, however, is not the raising of common "questions" - even in droves - but, rather, the capacity of a class-wide proceeding to generate common answers apt to drive the resolution of the litigation. Dissimilarities within the proposed class are what have the potential to impede the generation of common answers.

... The language in Rule 23(b)(3) tends to obscure this point, however, by asking whether "questions of law or fact common to class members predominate over any questions affecting only individual [class]

166 Richard A. Nagareda, Class Certification in the Age of Aggregate Proof, 84 N.Y.U. L. REV. 97, 131-32 (2009).

${ }^{167}$ Dukes, 131 S. Ct. at 2551 (alteration in original) (quoting Nagareda, supra note 166, at 131-32).

${ }^{168}$ Id. (quoting Nagareda, supra note 166, at 132). 
members." Heaps of similarities do not overcome dissimilarities that would prevent common resolution. ${ }^{169}$

Although it is clear that Professor Nagareda's discussion suggested that the presence of common questions of law or fact was not sufficient for class certification, that is a mere truism, for commonality is but one of several requirements for class certification in Rule 23. Professor Nagareda's real point was that predominance is the key and it should be interpreted in a way that permits critical dissimilarities to undermine certification even in the presence of "droves" of common questions that are less central. That is certainly a valuable insight that the Court might be advised to consider the next time it is tasked with interpreting the predominance requirement of Rule 23(b)(3). But turning this suggested understanding of predominance into the equivalent of commonality itself was in no way Professor Nagareda's end or something that his article's language supports. Nowhere does Professor Nagareda use his formulation to suggest that no common questions exist within the meaning of Rule 23(a)(2). He argues instead that predominance properly construed would look to what is uncommon among the class and evaluate the ability of those differences to frustrate the benefits of class treatment. ${ }^{170}$

The Court's commonality-as-centrality interpretation can thus draw no comfort from being derived from some other source, let alone from the text of the rule. ${ }^{171}$ Instead, it is the Dukes majority's own creation. Rather than amending the rule to reflect this approach, however, the Court found it more convenient to let a revised "interpretation" of commonality accomplish the same end, a technique it recently showcased in the Rule 8 context. ${ }^{172}$ Unfortunately, requiring common questions to be central ones will now require

${ }^{169}$ Nagareda, supra note 166, at 131-32 (emphasis added) (quoting FED. R. CIv. P. 23(b)(3))

170 Dean Klonoff aptly criticizes Justice Scalia's misrepresentation of Professor Nagareda's position on commonality by highlighting the latter's work on the ALI's Principles of the Law of Aggregate Litigation project. See Klonoff, supra note 22 (manuscript at 52). The portions of those principles authored by Professor Nagareda affirm the traditional understanding of commonality as a minimal requirement that did not demand issues whose disposition would resolve all contested issues in the litigation. See id. (manuscript at 51-53) ("Common issues are those legal or factual issues that are the same in functional content across multiple civil claims, regardless of whether their disposition would resolve all contested issues in the litigation." (emphasis added) (quoting PRINCIPLES OF THE LAW OF AGgREGATE Litigation $§ 2.01$ (2010))).

171 The textual arguments offered above, see supra text accompanying notes 128-30, apply equally to the Court's centrality requirement and need not be repeated here.

172 Ashcroft v. Iqbal, 556 U.S 662, 677-80 (2009) (applying Twombly's narrow interpretation of Rule 8 of the Federal Rules of Civil Procedure to dismiss a plaintiff's claim for lack of "facial plausibility"); Bell Atlantic Corp. v. Twombly, 550 U.S. 544, 545 (2007) (interpreting Rule 8 of the Federal Rules of Civil Procedure to require factual allegations sufficient "to raise a right to relief above the speculative level," in contrast with prior caselaw interpreting Rule 8 more broadly). 
courts to spin their wheels to refine the meaning of "central," a topic on which wide disagreements are certain to emerge. More disturbingly, the centrality requirement will permit courts to disregard common questions of law or fact that plainly exist and can be easily described, a liberty taken by the Dukes majority itself. ${ }^{173}$ Further, reinterpreting commonality in this way exports predominance outside of the Rule 23(b)(3) damages class context into being relevant to the certification of all kinds of classes under the guise of commonality. ${ }^{174}$ That inappropriately ratchets up the class certification standards for mandatory classes and makes it more difficult for such classes to succeed. ${ }^{175}$

\section{The Efficiency Requirement}

We turn finally to the "in one stroke" efficiency requirement of heightened commonality. This requirement is merely the cousin of the centrality requirement, as efficiency increases in proportion to the significance of the common questions that are present. As is the case with centrality, efficiency is an attribute reflected in the predominance criterion of Rule 23(b)(3). Observe the Advisory Committee's explanation of predominance in its notes to the adoption of the 1966 amendment to Rule 23:

${ }^{173}$ Here are some of the common questions of law or fact that were present in Dukes but were ignored as insufficient under the heightened commonality rule pronounced by the majority in that case: do local Wal-Mart managers exercise discretion over pay and promotion decisions in a manner that leads to a disparate adverse impact on female employees? Is Wal-Mart aware of this effect? Does Wal-Mart's awareness of this effect constitute disparate treatment under 42 U.S.C. $\S 2000 \mathrm{e}-2(\mathrm{a})$ ? Does Wal-Mart have a uniform company policy requiring a willingness to relocate as a prerequisite of promotion to management jobs? Does that policy have a disparate impact on women? Is such disparate impact unlawful under 42 U.S.C. $\S 2000 \mathrm{e}-2(\mathrm{a})$ ? The district court in Dukes discussed several common questions, including whether "Wal-Mart's policies governing compensation and promotions build in a common feature of excessive subjectivity which provides a conduit for gender bias." Dukes v. Wal-Mart Stores, Inc., 22 F.R.D. 137, 145 (N.D. Cal. 2004); see also Dukes, 131 S. Ct. at 2564 (Ginsburg, J., concurring in part and dissenting in part) ("The District Court's identification of a common question, whether WalMart's pay and promotions policies gave rise to unlawful discrimination, was hardly infirm."); id. at 2565 ("The Court gives no credence to the key dispute common to the class: whether Wal-Mart's discretionary pay and promotion policies are discriminatory.").

174 See Dukes, 131 S. Ct. at 2561-62 (Ginsburg, J., concurring in part and dissenting in part) ("In so ruling, the Court imports into the Rule 23(a) determination concerns properly addressed in a Rule 23(b)(3) assessment."); id. at 2566 ("Because Rule 23(a) is also a prerequisite for Rule 23(b)(1) and Rule 23(b)(2) classes, the Court's 'dissimilarities' position is far reaching. Individual differences should not bar a Rule 23(b)(1) or Rule 23(b)(2) class, so long as the Rule 23(a) threshold is met.").

175 Id. at 2565 ("The Court blends Rule 23(a)(2)'s threshold criterion with the more demanding criteria of Rule 23(b)(3), and thereby elevates the (a)(2) inquiry so that it is no longer "easily satisfied."' (quoting MOORE, supra note 11, § 23.23[2])). 
The court is required to find, as a condition of holding that a class action may be maintained under this subdivision, that the questions common to the class predominate over the questions affecting individual members. It is only where this predominance exists that economies can be achieved by means of the class-action device. ${ }^{176}$

This is not to say that other class certification prerequisites do not speak to efficiency or that it is only through requiring predominance that efficiency is secured. ${ }^{177}$ Hoping that resolution of common questions will "'generate common answers apt to drive the resolution of the litigation""178 is not an illegitimate goal per se, it just happens not to be what defines the meaning of commonality. Put differently, the spirit of Rule 23(a)(2) may be to achieve a certain end, efficiency. But that is a separate question from what the text of the rule says and requires. In the presence of ambiguity, it may become profitable to consult the policy behind a rule to comprehend its meaning. As Justice Scalia himself has admonished, however, "[W]hen the text of the rule is clear, that is the end of the matter." 179 Certainly no ambiguity presents itself in Rule 23(a)(2), which requires a "question" that is "common" to the class. Rather than follow his own textualist diktats, Justice Scalia pronounces efficiency as the objective policed by the commonality rule, then uses that to banish those common questions that do little to further efficiency from its ambit, without regard to the fact that commonality, not efficiency, is the unambiguous requirement of Rule 23(a)(2). ${ }^{180}$ The result is the very "practical threat" that Justice Scalia identified as flowing from the exaltation of intent over text: "The practical threat is that, under the guise or even the self-delusion of pursuing unexpressed legislative intents, common-law judges will in fact pursue their own objectives and desires, extending their lawmaking proclivities from the common law to the statutory field."181 Well stated, and apropos of Dukes.

\footnotetext{
176 FED. R. Civ. P. 23(b)(3) (1966) advisory committee's note.
}

177 Gen. Tel. Co. of the Sw. v. Falcon, 457 U.S. 147, 157 n.13 (1982) ("Both [commonality and typicality] serve as guideposts for determining whether under the particular circumstances maintenance of a class action is economical and whether the named plaintiff's claim and the class claims are so interrelated that the interests of the class members will be fairly and adequately protected in their absence.").

178 Dukes, 131 S. Ct. at 2551 (emphasis omitted) (quoting Nagareda, supra note 166, at 132).

179 Scalia, supra note 1, at 16.

180 Cf. Eisen v. Carlisle \& Jacquelin, 417 U.S. 156, 176 (1974) ("The short answer to these arguments is that individual notice to identifiable class members is not a discretionary consideration to be waived in a particular case. It is, rather, an unambiguous requirement of Rule 23.”).

181 Scalia, supra note 1, 17-18. 
A class should certainly not be certified merely because it presents common questions of law or fact, even in "droves." It may also be readily conceded that class certification is appropriate when important issues unite class claims or when class members all suffer the same injury. But Rule 23 does not make class certification turn on the basis of common questions alone, nor does it limit its use to circumstances in which class members are bound only by the central issue in the case. More important, the common question provision of Rule 23 imposes not one of the requirements that characterize heightened commonality after Dukes. In taking this approach, the Court is reviving the nineteenth- and early twentieth-century tradition under the codes of giving strict, narrowing constructions to statutory texts expressly drafted and designed to liberalize joinder. ${ }^{182}$ As discussed further in Part III, this revival is reflective of a wider move toward restrictiveness in civil procedure.

\section{HEIGHTENED COMMONALITY AND THE RESTRICTIVE ETHOS IN CIVIL PROCEDURE}

In a previous article, ${ }^{183}$ I described what I call the "restrictive ethos" in civil procedure - to be contrasted with the "liberal ethos" of the Progressive-era civil rulemakers ${ }^{184}$ - as the contemporary theme underlying certain procedural doctrines and rule interpretations that disserve access to civil justice. ${ }^{185}$

182 See Recent Trends in Joinder of Parties, Causes, and Counterclaims, 37 ColuM. L. REV. 462, 470 (1937) ("[J]udicial construction [of the codes] has narrowly confined both the broad provisions for joinder of parties and the terms 'arising out of the same transaction' ... so as to resurrect common law distinctions." (footnote omitted)).

183 Spencer, supra note 43, at 353-54.

184 Richard L. Marcus, The Revival of Fact Pleading Under the Federal Rules of Civil Procedure, 86 COLUM. L. REv. 433, 439 (1986) ("Dean Clark and the other drafters of the Federal Rules set out to devise a procedural system that would install what may be labeled the 'liberal ethos,' in which the preferred disposition is on the merits, by jury trial, after full disclosure through discovery." (citing Charles E. Clark, The Handmaid of Justice, 23 WASH. U. L.Q. 297, 318-19 (1938))); Arthur R. Miller, Are the Federal Courthouse Doors Closing? What's Happened to the Federal Rules of Civil Procedure?, 43 TEX. TECH. L. REv. 587, 587-88 (2011) ("When the Federal Rules were promulgated - that was in 1938, over 70 years ago - they had a very liberal ethos to them. As a result, the Rules established a relatively plainly worded, non-technical procedural system. The rulemakers believed in citizen access to the courts and in the resolution of disputes on their merits." (footnotes omitted)).

185 Spencer, supra note 43, at 353-54; see also Laurens Walker, The Other Federal Rules of Civil Procedure, 25 REv. LiTIG. 79, 80-81 (2006) ("[T]he rich context of common law procedural rules that function in conjunction with the 1938 Rules to determine the actual function of the federal district courts has not yet received any systematic analysis and comment. Among these background rules are, for example, heightened pleading requirements, the burdens of production and persuasion, and the doctrine of res judicata. These Other Federal Rules of Civil Procedure Rules are the subject of this article. My thesis is straightforward: The Other Rules interact with the 1938 Rules in such a way as to counter 
Specifically, restrictive procedural doctrines are those reflective of a bias against claimants from societal outgroups asserting disfavored claims against members of the dominant class. ${ }^{186}$ This bias manifests itself in a threshold skepticism that raises the bar for entry into the judicial system in these cases, frustrating the ability of such claimants to reach an authoritative resolution of their claims on the merits. ${ }^{187}$ In Dukes we have a new specimen of this phenomenon that both buttresses and helps to further explicate the restrictiveness thesis. It does so in three ways.

\section{A. Threshold Skepticism}

The Dukes majority indicated that a "rigorous" analysis of the evidence supporting commonality was necessary, ${ }^{188}$ with the employment discrimination context demanding "significant proof" of a general policy of discrimination. ${ }^{189}$ By endorsing a "rigorous" probe into the proofs offered by the plaintiffs of their collective claims, the Dukes majority demonstrated threshold skepticism, using its prejudgments about the merits as a guide to its resolution of the procedural question before it. Threshold skepticism ${ }^{190}$ demands that before a court permits defendants to be subjected to the litigation process itself - which is generally derided as being so expensive as to coerce undeserved settlements - claimants must demonstrate, up front, that their claims have merit. ${ }^{191}$ The

the apparent progressive character of the 1938 Rules and produce a functioning system which is not progressive in reality but conservative.").

186 I have previously cited the heightened pleading doctrine emanating from the $T$ wombly and Iqbal cases as an example. See A. Benjamin Spencer, Iqbal and the Slide Toward. Restrictive Procedure, 14 LEWIS \& CLARK L. REv. 185, 200 (2010) ("Iqbal reflects a certain judicial mood toward litigation, an attitude of hostility and skepticism toward supplicants with alleged grievances against the government or against the powerful who make up the dominant class.").

187 Spencer, supra note 43, at 359-66 (describing procedural doctrines that reflect threshold skepticism); A. Benjamin Spencer, Plausibility Pleading, 49 B.C. L. REv. 431, 460 (2008) (arguing that the heightened pleading standard of Twombly will "creat[e] a class of disfavored actions in which plaintiffs will face more hurdles to obtaining a resolution of their claims on the merits").

188 Wal-Mart Stores, Inc. v. Dukes, 131 S. Ct. 2541, 2551 (2011) (“We recognized in Falcon that 'sometimes it may be necessary for the court to probe behind the pleadings before coming to rest on the certification question,' and that certification is proper only if 'the trial court is satisfied, after a rigorous analysis, that the prerequisites of Rule 23(a) have been satisfied."' (quoting Gen. Tel. Co. of the Sw. v. Falcon, 457 U.S. 147, 160, 161 (1982))).

189 Id. at 2553.

190 This Article's discussion of "threshold skepticism" is to be distinguished from the idea of the majority's skepticism of discrimination claims per se. It addresses the latter type of skepticism in its discussion of the Court's bias against claimants from outgroups and treatment of discrimination claims as disfavored actions. See infra Part III.C.

191 See, e.g., Bell Atlantic Corp. v. Twombly, 550 U.S. 544, 557-58 (2007) 
majority exhibited such skepticism in Dukes by assessing the value and weight of the evidence presented by the class members regarding their discrimination claims and found the evidence completely wanting: "Because respondents provide no convincing proof of a companywide discriminatory pay and promotion policy, we have concluded that they have not established the existence of any common question."192

The problem with this approach is that it seems to run counter to the Court's previous pronouncement in Eisen v. Carlisle \& Jacquelin"193 that "nothing in either the language or history of Rule 23 [] gives a court any authority to conduct a preliminary inquiry into the merits of a suit in order to determine whether it may be maintained as a class action." 194 Further, no matter how "rigorous" such merits reviews are purported to be, in truth they are cursory quick peeks that not only fail to measure up to the thorough consideration of the merits that district courts can provide, but they also improperly displace them. Even in the class context, appellate courts are not in the position to provide de novo review of factual evidence, giving their own assessments without regard to the findings of the district court. ${ }^{195}$ This is especially so at the certification stage, where an appellate court may cherry-pick facts from an underdeveloped factual record in support of its commonality assessment. Though an appellate-level merits review is inevitably less thorough and sound than that which can be provided by the district court, the Dukes majority engaged in what it considered to be a "rigorous" search for "significant proof" of a general policy of discrimination. ${ }^{196}$ That meant a heightened evidentiary standard was being imposed in the context of a preliminary, yet appellate, review of the facts, something that was unfair to the plaintiffs. ${ }^{197}$ To the extent

("[S]omething beyond the mere possibility of loss causation must be alleged, lest a plaintiff with 'a largely groundless claim' be allowed to 'take up the time of a number of other people, with the right to do so representing an in terrorem increment of the settlement value.'” (quoting Dura Pharm., Inc. v. Broudo, 544 U. S. 336, 347 (2005))).

192 Dukes, 131 S. Ct. at 2556-57.

193417 U.S. 156 (1974).

194 Id. at 177; see also id. at 178 ("'In determining the propriety of a class action, the question is not whether the plaintiff or plaintiffs have stated a cause of action or will prevail on the merits, but rather whether the requirements of Rule 23 are met."' (quoting Miller v. Mackey Int'l, Inc., 452 F.2d 424, 427 (5th Cir. 1971))).

195 Dukes, 131 S. Ct. at 2564 n.5 (Ginsburg, J., concurring in part and dissenting in part) ("Appellate review is no occasion to disturb a trial court's handling of factual disputes of this order.”); Califano v. Yamasaki, 442 U.S. 682, 703 (1979) (“[M]ost issues arising under Rule 23 [are] committed in the first instance to the discretion of the district court.").

196 Dukes, 131 S. Ct. at 2553. The majority quoted favorably Falcon's requirement of showing "“[s]ignificant proof that an employer operated under a general policy of discrimination."' Id. (quoting Gen. Tel. Co. of the Sw. v. Falcon, 457 U.S. 147, 159 n.15 (1982)).

197 Cf. Eisen, 417 U.S. at 178 ("Additionally, we might note that a preliminary determination of the merits may result in substantial prejudice to a defendant, since of 
the Dukes majority is endorsing a rigorous review of factual questions that otherwise would warrant jury treatment, this approach echoes the jurydisplacing effects of the Court's restrictive moves in the areas of summary judgment ${ }^{198}$ and pleading doctrine. ${ }^{199}$ In making this endorsement, the Dukes majority acknowledged that a likely post-certification settlement will preempt most jury trials in the class action context. ${ }^{200}$ In any event, merely requiring such proof at the certification stage raises the cost of certification and diminishes the chance of successful certification. ${ }^{201}$

What is more fundamentally wrong with this threshold skepticism is its infusion into the commonality analysis. A court may rightfully be skeptical of class certification and take all necessary steps to ensure that claims have merit before permitting them to proceed, provided that the procedural hurdle at issue makes the merits relevant. ${ }^{202}$ But resting such skepticism on the back of a requirement as simple and straightforward as one that asks only for "questions of law or fact common to the class" is going too far. And that is the point: Threshold skepticism is not objectionable per se; what makes it illegitimate is when innocent provisions are conscripted into service of its ends. As the Court at another time concluded, it would be better to use the process for formally amending the rule than to in fuse it with an alien reading to suit its members' policy prerogatives, ${ }^{203}$ even if such policy is to make sure that the

necessity it is not accompanied by the traditional rules and procedures applicable to civil trials. The court's tentative findings, made in the absence of established safeguards, may color the subsequent proceedings and place an unfair burden on the defendant.").

198 See Suja A. Thomas, Why Summary Judgment Is Unconstitutional, 93 VA. L. REV. 139, 144 (2007).

199 See Suja A. Thomas, Why the Motion to Dismiss Is Now Unconstitutional, 92 MINN. L. REv. 1851, 1867-68 (2008).

200 Dukes, 131 S. Ct. at 2551-52; see also Szabo v. Bridgeport Machs., Inc., 249 F.3d 672, 676 (7th Cir. 2001) ("[A]n order certifying a class usually is the district judge's last word on the subject; there is no later test of the decision's factual premises (and, if the case is settled, there could not be such an examination even if the district judge viewed the certification as provisional). Before deciding whether to allow a case to proceed as a class action, therefore, a judge should make whatever factual and legal inquiries are necessary under Rule 23.").

201 See Rutherglen, supra note 33, at 29 (stating that "requiring such evidence raises the cost to the plaintiffs of obtaining a favorable ruling on certification" and diminishes the prospect of certification).

202 See George Rutherglen, The Way Forward After Wal-Mart 3 (Virginia Pub. Law and Legal Theory, Research Paper No. 2012-56, 2012), available at http://ssm.com/abstract $=21$

47955 ("Even such seemingly 'trans-substantive' requirements as adequacy of representation can be implemented only by reference to substantive law. Whether there are conflicts of interest within the class, or whether the class attomey can effectively represent the class, cannot be decided without considering substantive law.").

203 See, e.g., Swierkiewicz v. Sorema, 534 U.S. 506, 514-15 (2002) ("Whatever the practical merits of this argument, the Federal Rules do not contain a heightened pleading 
consequential decision of permitting a class to go forward is only done when there is some assurance that the plaintiffs' claims are meritorious. In the end, what is troubling about this kind of threshold skepticism and the restrictive ethos in general is that it operates sub terra. Rules are not formally amended so that movement in the desired direction can be debated and vetted, transparent and democratic; rather, rules are contorted to mean what they do not say to dictate a result desired by their interpreters, not their drafters. Two plus two equals five. ${ }^{204}$

\section{B. Disfavored Actions}

The second way in which Dukes exemplifies the restrictive ethos in civil procedure is that it heightens entry standards in the context of discrimination claims, a type of claim that historically has been treated as disfavored, ${ }^{205}$ particularly when advanced by members of outgroups. ${ }^{206}$ From motions for sanctions under Rule 11, to summary judgment motions, to pleading standards,

standard for employment discrimination suits. A requirement of greater specificity for particular claims is a result that 'must be obtained by the process of amending the Federal Rules, and not by judicial interpretation."' (quoting Leatherman v. Tarrant Cnty. Narcotics Intelligence and Coordination Unit, 507 U.S. 163, 168 (1993))). Indeed, a proposal to amend Rule 23 to permit explicit evaluation of the merits as part of the certification stage was considered but never approved by the Advisory Committee. Memorandum from Patrick E. Higginbotham, Chair, Advisory Comm. on Civil Rules, to Members of the Standing Comm. on Rules (Dec. 13, 1995), available at http://www.uscourts.gov/uscourts/RulesAndP olicies/rules/Reports/CV12-1995.pdf (discussing a proposed draft amendment of Rule 23(b)(3) that would have required a consideration of whether "the prospect of success on the merits of the class claims, issues, or defenses is sufficient to justify the costs and burdens imposed by certification").

204 GeORGE Orwell, 1984, at 69 (New American Library 1981) (1949) ("In the end, the Party would announce that two and two made five and you would have to believe it.").

${ }^{205}$ See A. Benjamin Spencer, Pleading Civil Rights Claims in the Post-Conley Era, 52 How. L.J. 99, 111-18 (2008) (discussing the history of heightened pleading in the context of civil rights claims); id. at 141 ("Particularized fact-pleading of the kind prevalent prior to Swierkiewicz and resurgent during the period leading up to Twombly seems to have persisted as the standard of pleading applied by many, if not most, lower federal courts in civil rights cases.").

206 When discrimination claims are asserted by members of dominant groups - white Americans in this country - the Court seems much more solicitous. See, e.g., Parents Involved in Cmty. Schs. v. Seattle Sch. Dist. No. 1, 551 U.S. 701, 710-11 (2007) (Roberts, C.J., plurality opinion) (upholding a challenge by parents of white children of the Seattle school system's race-conscious school assignment system); Gratz v. Bollinger, 539 U.S. 244, 275-76 (2003) (upholding a challenge by rejected white applicants to the University of Michigan's use of race in its admissions process); Regents of the Univ. of Cal. v. Bakke, 438 U.S. 265, 271 (1978) (opinion of Powell, J.) (upholding challenge by rejected white medical school applicant of the school's use of race in its admissions process). For an elaboration on this point, see infra Part III.C. 
employment discrimination claims ${ }^{207}$ have faced a gauntlet of procedural hurdles that otherwise do not apply to civil actions. ${ }^{208}$ Why are discrimination claims disfavored? At bottom, it appears that jurists who disfavor these claims do so because they do not believe in them. They seem to espouse a deep suspicion of, or at least a doubt concerning, claims of mistreatment tied to a person's race or gender, believing that the vast majority of people do not discriminate and instead treat each other fairly. ${ }^{209}$ Explicit evidence of racial animus is demanded before this presumption can be overcome. ${ }^{210}$ This is a Pollyannish, counter-factual worldview ${ }^{211}$ but appears to be widely held. ${ }^{212}$ For

207 This ratcheting up of procedural requirements has not been confined to employment discrimination claims, but rather has occurred with respect to other disfavored actions as well. Spencer, supra note 43, at 371 ("Other actions have been 'disfavored' as well; malicious prosecution, civil-rights claims, securities claims, and antitrust claims have been treated by various courts throughout the history of the Federal Rules as disfavored and thus warranting a heightened pleading standard.").

208 See id. (describing the heightened scrutiny given to employment discrimination claims in these contexts).

209 See Vicki Schultz \& Stephen Petterson, Race, Gender, Work and Choice: An Empirical Study of the Lack of Interest Defense in Title VII Cases Challenging Job Segregation, 59 U. CHI. L. REV. 1073, 1180 (1992) (“After a decade of effiorts to enforce Title VII, federal judges apparently began to share the general public's belief that employment discrimination against minorities had been largely eradicated."); see also Suzette M. Malveaux, Clearing Civil Procedural Hurdles in the Quest for Justice, 37 Онго N.U. L. REV. 621, 624-25 (2011) ("With the election of Barack Obama, the first African American President, there has been a particularly acute focus on whether American society has become 'post-racial.' Following this historic election, many Americans have concluded that race discrimination is no longer a significant issue. Consequently, some judges, like many other Americans, may operate from the presumption that race discrimination is a thing of the past." (footnotes omitted)).

210 See Melissa Hart, Subjective Decisionmaking and Unconscious Discrimination, 56 ALA. L. REV. 741, 789-90 (2005); id. at 789 n.258 ("In the early years of [Title VII's] application, courts tended to operate on the assumption that if an employment decision was unexplained, or the explanation made no sense or lacked support, it was likely that the decision involved discrimination. That assumption has shifted, and many judges today instead presume that the employer who is unwilling or unable to explain a decision may have acted with personal animosity - which is not prohibited by law - rather than discriminatory animus." (citation omitted)); see also Thomas v. Troy City Bd. of Educ., 302 F. Supp. 2d 1303, 1309 (M.D. Ala. 2004) ("The judicial focus on the search for unconstitutional discriminatory animus obscures the fact that it is possible that the board chose the individual it perceived to be the 'best' candidate and, yet still, that Thomas was subjected to discrimination; the two are not mutually exclusive.").

211 See Charles R. Lawrence III, The Id, the Ego, and Equal Protection: Reckoning with Unconscious Racism, 39 STAN. L. REV. 317, 324-25 (1987) ("By insisting that a blameworthy perpetrator be found before the existence of racial discrimination can be acknowledged, the Court creates an imaginary world where discrimination does not exist unless it was consciously intended."). 
example, Chief Justice John Roberts's remark that "[t]he way to stop discrimination on the basis of race is to stop discriminating on the basis of race"213 evinces his oblivity to the existence of covert or unintentional discrimination that is preconscious, ${ }^{214}$ mediated by some other trait, ${ }^{215}$ or derivative of classifications or assumptions that are neither gender nor race based. 216

The last-mentioned of these types of discrimination to which Chief Justice Roberts is oblivious characterizes the kinds of claims advanced by the Dukes

212 See, e.g., K.A. Dixon ET AL., John J. Heldrich CTR. FOR WORKFORCE DEV., A WorkPlace Divided: HOW AMERICANS VIEW DisCRIMINATION AND RACE ON THE JOB 8

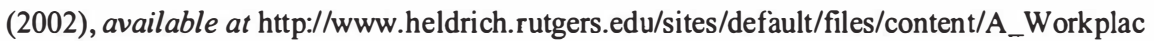

e_Divided.pdf ("Half of African-American workers believe that African Americans are treated unfairly in the workplace compared to $10 \%$ of white workers, and $13 \%$ of workers from other racial backgrounds."); id. at 14 (finding that only $6 \%$ of white workers believe that promotions are awarded in a way that is unfair to African Americans, compared with $46 \%$ of African Americans who share that belief); see also Suzette M. Malveaux, Front Loading and Heavy Lifting: How Pre-Dismissal Discovery Can Address the Detrimental Effeect of Iqbal on Civil Rights Cases, 14 LEwIS \& CLARK L. REv. 65, $93-94$ (2010) (discussing this view and citing several reports and other sources in support).

${ }^{213}$ Parents Involved in Cmty. Schs. v. Seattle Sch. Dist. No. 1, 551 U.S. 701,748 (2007).

214 See Kerry Kawakami, Kenneth L. Dion \& John F. Dovidio, Implicit Stereotyping and Prejudice and the Primed Stroop Task, 58 SwiSs J. Psychol. 241, 246-47 (1999) ("[T]he present study offiers further evidence that racial stereotypes and attitudes can be activated without intention."); see also Hart, supra note 210, at 743 ("Contemporary sociological and psychological research reveals that discriminatory biases and stereotypes are pervasive, even among well-meaning people. In fact, recent studies have focused particular attention on the unconscious biases of people whose consciously held beliefs are strongly egalitarian."). In her Dukes opinion, Justice Ginsburg remarked that "[m]anagers, like all humankind, may be prey to biases of which they are unaware" and cited a study on blind auditions for orchestras as an example. See Wal-Mart Stores, Inc. v. Dukes, 131 S. Ct. 2541, 2563 (2011) (Ginsburg, J., concurring in part and dissenting in part) (citing Claudia Goldin \& Cecilia Rouse, Orchestrating Impartiality: The Impact of "Blind" Auditions on Female Musicians, 90 AM. ECON. REv. 715, 715-16(2000)).

215 Marianne Bertrand \& Sendhil Mullainathan, Are Emily and Greg More Employable than Lakisha and Jamal? A Field Experiment on Labor Market Discrimination, 94 AM. ECON. REV. 991, 991 (2004) ("White names receive 50 percent more callbacks for interviews [than African American sounding names]. Callbacks are also more responsive to resume quality for White names than for African American ones. The racial gap is uniform across occupation, industry, and employer size. We also find little evidence that employers are inferring social class from the names. Differential treatment by race still appears to still be prominent in the U.S. labor market.").

216 See Dukes, 131 S. Ct. at 2563 (Ginsburg, J., concurring in part and dissenting in part) ("Absent instruction otherwise, there is a risk that managers will act on the familiar assumption that women, because of their services to husband and children, are less mobile than men." (citing Fed. Glass Ceiling Comm'n, DeP'T of Labor, GoOd for Business: Making Full Use of the Nation's Human Capit Al 151 (1995))). 
plaintiffs: "Wal-Mart has maintained a 'willingness to relocate' prerequisite for promotion to management which has had a disparate impact on plaintiffs and the class they represent." 217 The Dukes plaintiffs also sought to challenge implicit gender bias that manifesied itself through the policy of excessive subjective decisionmaking with respect to pay and promotion decisions, something the Court had previously suggested it understood to be a problem that a Title VII claim could address:

[I]t may be customary and quite reasonable simply to delegate employment decisions to those employees who are most familiar with the jobs to be filled and with the candidates for those jobs. It does not follow, however, that the particular supervisors to whom this discretion is delegated always act without discriminatory intent. Furthermore, even if one assumed that any such discrimination can be adequately policed through disparate treatment analysis, the problem of subconscious stereotypes and prejudices would remain... If an employer's undisciplined system of subjective decisionmaking has precisely the same effects as a system pervaded by impermissible intentional discrimination, it is difficult to see why Title VII's proscription against discriminatory actions should not apply. In both circumstances, the employer's practices may be said to "adversely affect [an individual's] status as an employee, because of such individual's race, color, religion, sex, or national origin." We conclude, accordingly, that subjective or discretionary employment practices may be analyzed under the disparate impact approach in appropriate cases. ${ }^{218}$

Certainly, the "problem of subconscious stereotypes and prejudices" belies Chief Justice Roberts's simplistic admonition to just "stop" discriminating so that discrimination may end.

Justice Scalia, too, is hobbled by this naïve mindset, which he showcases in his crabbed commonality analysis in Dukes. Having declared that central common questions are the only ones that suffice, Justice Scalia demands that the plaintiffs prove one of two commonalities to demonstrate employment discrimination. Plaintiffs may either show use of "a biased testing procedure" that prejudiced all class members or offer "significant proof that an employer operated under a general policy of discrimination." 219 With the former not being implicated in the case, attention focused on the policy question. Justice Scalia concluded that because "Wal-Mart's announced policy forbids sex discrimination" and the presence of a gender-biased corporate culture could not be demonstrated to his satisfaction, no "significant proof" of a

\footnotetext{
217 Plaintiffs' Third Amended Complaint, supra note 16, at 22.

218 Watson v. Fort Worth Bank \& Trust, 487 U.S. 977, 990-91 (1988) (alteration in original) (citation omitted) (quoting 42 U.S.C. § 2000e-2(a)(2) (1982)).

${ }^{219}$ Dukes, 131 S. Ct. at 2553.
} 
discriminatory policy existed. ${ }^{220}$ The only evidence of a policy that Justice Scalia credited was Wal-Mart's policy of permitting local supervisors to exercise discretion regarding pay and promotion decisions. In the context of such discretion, however, Justice Scalia baldly posits that discrimination is unlikely in most cases: "[L]eft to their own devices most managers in any corporation - and surely most managers in a corporation that forbids sex discrimination - would select sex-neutral, performance-based criteria for hiring and promotion that produce no actionable disparity at all." 221 Apparently not:

Women fill 70 percent of the hourly jobs in [Wal-Mart's] stores but make up only 33 percent of management employees. The higher one looks in the organization the lower the percentage of women. The plaintiffs' largely uncontested descriptive statistics also show that women working in the company's stores are paid less than men in every region and that the salary gap widens over time even for men and women hired into the same jobs at the same time. . $^{22}$

Notwithstanding these facts, because of Justice Scalia's belief that intentional discrimination is only personal unless it can be evidenced by "significant proof" of some formal discriminatory policy, he concludes that "[a] party seeking to certify a nationwide class will be unable to show that all the employees' Title VII claims will in fact depend on the answers to common questions." 223

Ultimately, serious doubts about the existence of group bias within an organization that is pervasive, cultural, and unconscious or condoned - but not always express - is what made the Dukes claims disfavored and misunderstood. That attitude, in turn, yielded a disbelief that important commonalities could exist, since discrimination is personal and must be detected on a case-by-case basis absent a formal, global policy. By ratcheting up commonality to require central common questions and then defining what that question must be in the employment-discrimination context, the Dukes majority was able to operationalize its doubt-of-group-bias perspective under the guise of the common question requirement and forestall the prosecution of these disfavored claims. ${ }^{224}$

220 Id. at 2553-54.

221 Id. at 2554.

222 Id. at 2563 (Ginsburg, J., concurring in part and dissenting in part) (citations omitted) (internal quotation marks omitted).

223 Id. at 2254 (majority opinion).

${ }^{224}$ The majority may have also reshaped Title VII law in rejecting the sufficiency of disparate impact in the context of a discretionary system to establish unlawful discrimination. Compare id. at 2555 ("[P]roving that [a] discretionary system has produced a . . . disparity is not enough."), with id. at 2565 (Ginsburg, J., concurring in part and dissenting in part) (discussing a prior decision holding that an "employer's 'undisciplined system of subjective decisionmaking' was an 'employment practice' that 'may be analyzed under the disparate impact approach."' (quoting Watson v. Fort Worth Bank \& Trust, 487 


\section{Anti-Claimant Bias and Outgroups as Class Claimants}

A final but lesser point related to the treatment of disfavored claims is that Dukes seems to confirm that component of the restrictiveness thesis that posits a bias against the types of plaintiffs who typically bring such claims: members of societal outgroups. Members of societal outgroups are "those outside the political and cultural mainstream, particularly those challenging accepted legal principles and social norms .... [T] hose raising difficult and often tenuous claims that demand the reordering of established political, economic and social arrangements, that is, those at the system's and society's margins." 225 The restrictive ethos thesis suggests that when plaintiffs from such groups are pitted against societal insiders, procedure is interpreted in ways that thwart the plaintiffs' efforts. ${ }^{226}$ That is fairly descriptive of what happened in Dukes, which involved female employees complaining of discrimination in pay and promotion decisions by managerial personnel of Wal-Mart, the largest corporation in the world. ${ }^{227} \mathrm{~W}$ omen have historically been discriminated against in the employment context ${ }^{228}$ and continue to endure pay disparities ${ }^{229}$

U.S. 977, 990-91 (1988))). Professor Rutherglen has also made this observation. See Rutherglen, supra note 201, at 5 ("In the end, the decision in Wal-Mart may come to stand as much for its insistence on the strict standards of proof for class claims under Title VII as for its interpretation of the requirements of Rule 23."). Analyzing the impact of Dukes on Title VII law is beyond the scope of this Article.

${ }^{225}$ Eric K. Yamamoto, Efficiency's Threat to the Value of Accessible Courts for Minorities, 25 HaRv. C.R.-C.L. L. REv. 341, 345 (1990).

226 Spencer, supra note 43, at 353-54.

227 Global 500, FORTUNE (July 25, 2011 ), http://money.cnn.com/magazines/fortune/globa 1500/2011/snapshots/2255.html.

228 See Frontiero v. Richardson, 411 U.S. 677, 685-86 (1973) ("It is true, of course, that the position of women in America has improved markedly in recent decades. Nevertheless, it can hardly be doubted that, in part because of the high visibility of the sex characteristic, women still face pervasive, although at times more subtle, discrimination in our educational institutions, in the job market and, perhaps most conspicuously, in the political arena." (footnotes omitted)); see also Nev. Dep't of Human Res. v. Hibbs, 538 U.S. 721, 735 (2003) (“[T]he States' record of unconstitutional participation in, and fostering of, gender-based discrimination in the administration of leave benefits is weighty enough to justify the enactment of prophylactic $\S 5$ legislation."); The Family and Medical Leave Act of 1987: Joint Hearings Before the Subcomm. on Labor-Management Relations \& Subcomm. on Labor Standards of the H. Comm. on Educ. and Labor, 100th Cong. 235 (1987) (statement of Donna Lenhoff, Assoc. Dir. for Legal Pol'y \& Programs, Women's Legal Defense Fund) ("Historically, denial or curtailment of women's employment opportunities has been traceable directly to the pervasive presumption that women's place is in the home.").

229 White House COUNCIL ON WOMEN \& GiRLS, KeEPING AMERICA's WOMEN MOVING FORWARD: THE KEY TO AN ECONOMY BUILT TO LAST, at i (2012) ("[W]omen still make just 77 cents for every dollar men make . . .."); see also STAFF OF JOINT ECON. COMM., $111 \mathrm{TH}$

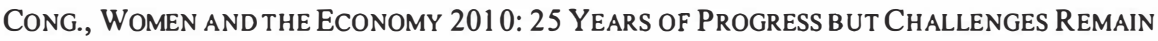
1 (Comm. Print 2010) (“[T]he average full-time working woman earns only 80 cents for 
and glass ceilings. ${ }^{230}$ Thus, in Dukes, when a massive group of working-class women presented quite plausible support for the idea that gender discrimination permeates the pay and promotion practices of a company the size of Wal-Mart, a majority of the Court found a way to thwart their claims. The Court did so not by confronting them on the merits, but by using an adulteration of the common question requirement for the task. And that is what characterizes the restrictive ethos: insider bias against claimants from societal outgroups feeds into interpreting procedure to raise the standards for entry in a way that aborts outsider claims ab initio. ${ }^{231}$ Certainly, this point regarding anticlaimant bias could be rightly characterized as an intuition; the point here, however, is to highlight Dukes as an additional data point in the ongoing analysis of whether such a bias indeed exists. Time will tell, but for now suffice it to say that Dukes fits this aspect of the restrictiveness critique.

Contrast this treatment of outsider plaintiffs with the solicitude that defendant corporations tend to receive in the face of the slightest litigation adversity. In AT\&T Mobility LLC v. Concepcion, ${ }^{232}$ the company challenged the class suit of customers on the basis that it violated the arbitration clauses in the customers' respective contracts. ${ }^{233}$ Justice Scalia expressed his sympathy for corporate defendants when he wrote:

[C]lass arbitration greatly increases risks to defendants.... [W] hen damages allegedly owed to tens of thousands of potential claimants are aggregated and decided at once, the risk of an error will often become unacceptable. Faced with even a small chance of a devastating loss, defendants will be pressured into settling questionable claims. ${ }^{234}$

Vulnerable corporations were also pitied in Bell Atlantic Corp. v. Twombly, 235 which involved an attempted class action alleging an antitrust conspiracy

every dollar earned by the average full-time working man.").

230 See U.S. Equal Emp't Opportunity Comm'n, Glass Ceilings: The Status of Women as Officials and Managers in the Private Sector, at i (2004) ("Women represent 48 percent of all employment, but represent only 36.4 percent of officials and managers. Women make up 80.3 percent of office and clerical workers."); see also INST. OF LEADERSHIP \& MGMT., AMBITION AND GENDER A T WORK 2 (2011) (“Our research found that three quarters $(73 \%)$ of women believe there are barriers preventing them from progressing to the top levels of management. .. Alongside well known obstacles to advancement such as maternity and childcare-related issues, the findings reveal a number of less conspicuous, but nevertheless critical, factors. In summary, the research reveals that women managers are impeded in their careers by lower ambitions and expectations.").

231 Professor Miller expressed a similar lament about the move toward restrictiveness more generally when he wrote, "[W]e are moving slowly toward a system in which an increasing number of civil actions may be stillborn." Miller, supra note 184, at 596.

232131 S. Ct. 1740 (2011).

233 Id. at $1744-45$.

234 Id. at 1752.

235550 U.S. 544 (2007). 
against regional telephone companies. ${ }^{236}$ There, rather than put the defendants through the trouble of filing an answer, the Court rejected the complaint for factual insufficiency, noting that "proceeding to antitrust discovery can be expensive" and that "the threat of discovery expense will push cost-conscious defendants to settle even anemic cases before reaching those proceedings." 237 Perhaps Chief Justice Rehnquist's fine tuning of summary judgment was the most solicitous of civil defendants when he wrote:

Rule 56 must be construed with due regard not only for the rights of persons asserting claims and defenses that are adequately based in fact to have those claims and defenses tried to a jury, but also for the rights of persons opposing such claims and defenses to demonstrate in the manner provided by the Rule, prior to trial, that the claims and defenses have no factual basis. ${ }^{238}$

In seeking to right the balance between claimants and defendants, these cases in truth tilted the balance in favor of the latter; Dukes is but the latest manifestation of this trend, placing a thumb on the scale in favor of Wal-Mart - and a finger in the eye of the Dukes plaintiffs - via the Court's heightening of commonality.

Dukes is merely the latest in a series of cases moving civil procedure in a restrictive direction. ${ }^{239}$ In J. McIntyre Machinery, Ltd. v. Nicastro, ${ }^{240}$ the Court used a heightened personal jurisdiction doctrine to protect a foreign corporate defendant against a suit by an individual plaintiff who had been severely injured by a product of the defendant shipped to the victim's state. ${ }^{241}$ The Court did so despite the fact that the defendant intentionally shipped its

${ }^{236} \mathrm{Id}$. at 550 .

237 Id. at 558-59.

${ }^{238}$ Celotex Corp. v. Catrett, 477 U.S. 317, 327 (1986); see also Eisen v. Carlisle \& Jacquelin, 417 U.S. 156, 176, 178 (1974) (“Additionally, we might note that a preliminary determination of the merits may result in substantial prejudice to a defendant, since of necessity it is not accompanied by the traditional rules and procedures applicable to civil trials. The court's tentative findings, made in the absence of established safeguards, may color the subsequent proceedings and place an unfair burden on the defendant.").

${ }^{239}$ Professor Miller critiques this trend as well: "The Court has given primacy to gate keeping. It has accorded efficiency and cost reduction the status of primary systemic objectives." Miller, supra note 184, at 597; see also Malveaux, supra note 209, at 621 ("Is there a crisis in the legal profession for civil litigants challenging systemic discrimination and other corporate misconduct? While it may not have reached epidemic proportions, plaintiffs are facing greater challenges bringing civil rights and consumer cases because of procedural hurdles in the civil litigation system.").

240131 S. Ct. 2780 (2011).

${ }^{241}$ Id. at 2785. 
product - a shearing machine for the production of scrap metal - to its distributor in Ohio for sale across the entire United States, including New Jersey, the largest market for scrap metal. ${ }^{242}$ Iqbal's and Twombly's respective heightenings of the general pleading standard under Rule 8 has already been mentioned and is treated more extensively elsewhere, ${ }^{243}$ as are other recent moves toward restrictive procedure. ${ }^{244}$ Only time will tell whether these cases portend a permanent shift away from access to justice. ${ }^{245}$ In any event, heightened commonality nicks away at access in ways that serve to provide some confirmation of the restrictive ethos thesis and move us further in the anti-access direction. ${ }^{246}$

242 Id. at 2795 (Ginsburg, J., dissenting).

243 See, e.g., Arthur R. Miller, From Conley to Twombly to Iqbal: A Double Play on the Federal Rules of Civil Procedure, 60 DUKE L.J. 1, 103-27 (2010); Spencer, supra note 187, at $460-89$. 43.

244 See generally Malveaux, supra note 209; Miller, supra note 184; Spencer, supra note

245 It must be noted that this trend is not uniform or uninterrupted. One can find procedural decisions by the Court that go the other way. See, e.g., Erica P. John Fund, Inc. v. Halliburton Co., 131 S. Ct. 2179, 2185-86 (2011) (stating that plaintiffs in a private securities fraud class action need not prove loss causation in order to obtain class certification); Shady Grove Orthopedic Assocs., P.A. v. Allstate Ins. Co., 130 S. Ct. 1431, 1438-39 (2010) (holding that Rule 23 of the Federal Rules of Civil Procedure trumps a conflicting New York law prohibiting class actions under certain circumstances). Cases such as these are arguably a challenge to the restrictiveness thesis, although I would argue that the preponderance of the procedural cases incline in a restrictive direction.

246 This is not to say that the march toward restrictiveness is uniform in that direction. For example, the Court ruled in favor of plaintiffs seeking the right to proceed under Rule 23 in a diversity case to enforce penalties that, under New York law, could not be litigated via the class action device. Shady Grove, $130 \mathrm{~S}$. Ct. at 1436-37, 1448. However, Shady Grove only goes so far; it was an endorsement for Rule 23 goveming the question of whether a class action may be entertained, not a decision that interpreted Rule 23 in a way that improved the class certification prospects of litigants who invoke the rule. Compare this "pro-plaintiff" decision with the Class Action Faimess Act of 2005, Pub. L. No. 109-2, 119 Stat. 4, which "expanded" litigant access to federal court so that proposed classes could be considered under the aegis of Rule 23, only to be held to higher certification standards on arrival - standards Congress hoped would scuttle, not facilitate, putative class actions. See S. REP. NO. 109-14, at 14 (2005) ("[O]ne reason for the dramatic explosion of class actions in state courts is that some state court judges are less careful than their federal court counterparts about applying the procedural requirements that govern class actions. . . . In contrast, federal courts generally scrutinize proposed settlements much more carefully and pay closer attention to the procedural requirements for certifying a matter for class treatment."). Further, Justice Scalia's endorsement of Rule 23 in Shady Grove is rooted in his adherence to the terms of the Rules Enabling Act and the belief that rules promulgated under that statute control the questions they embrace so long as they are procedural in nature. See Shady Grove, 130 S. Ct. at 1442 (opinion of Scalia, J.) ("What matters is what the rule itself regulates: If it governs only 'the manner and the means' by which the 


\section{CONCLUSION}

In truth, the meaning of the common question requirement of Rule 23(a) is self-evident as a matter of plain English. The history of the common question phrasing and of Rule 23 itself, as well as the practice under rules containing such language here and in England, however, make it clear that determining commonality is a simple matter of seeing what questions, if any, would be duplicated were each class claimant to proceed individually. For each claim asserted by the Dukes plaintiffs, a common legal question was whether WalMart's policy of excessive subjectivity in pay and promotion decisions by local supervisors violates Title VII. ${ }^{247}$ Although that common question or others may not have been good enough for the Dukes majority, they are good enough for the rule: "The text is the law, and it is the text that must be observed." 248

One might retort that had the Dukes plaintiffs been permitted to seek certification as a (b)(3) class, eventual application of its predominance requirement would likely yield the same result reached in Dukes, decertification of the class. That does not mean, however, that concern over heightened commonality is much ado about nothing. First, by conducting an implicit predominance analysis under the guise of commonality, parties get none of the benefit of the jurisprudence surrounding predominance that might otherwise be useful in litigating that question; rather, a new jurisprudence of centrality will emerge. Second, predominance is only a concem of (b)(3) class actions; smuggling such an inquiry into commonality makes predominance pertinent now to all types of class actions, a constraint unsupported by the text of Rule $23 .{ }^{249}$ Third, it matters that classes are decertified properly and not at the hands of judicially contrived restrictions. Policy considerations may certainly warrant a tightening of the standards for class certification, but that is a result that "must be obtained by the process of amending the Federal Rules, and not by judicial interpretation." 250 Finally, tightening up the meaning of

litigants' rights are 'enforced,' it is valid; if it alters 'the rules of decision by which [the] court will adjudicate [those] rights,' it is not." (alteration in original) (quoting Miss. Publ'g Corp. v. Murphree, 326 U.S. 438, 446 (1946))).

247 See Wal-Mart Stores, Inc. v. Dukes, 131 S. Ct. 2541, 2567 (2011) (Ginsburg, J., concurring in part and dissenting in part) ("A system of delegated discretion . . . is a practice actionable under Title VII when it produces discriminatory outcomes. A finding that WalMart's pay and promotions practices in fact violate the law would be the first step in the usual order of proof for plaintiffs seeking individual remedies for company-wide discrimination.").

248 Scalia, supra note 1, at 22.

249 Dean Klonoff makes this point as well. See Klonoff, supra note 22 (manuscript at 53) ("This new interpretation of commonality should not significantly impact (b)(3) classes, which require both commonality and predominance. The decision, however, could have a significant impact on (b)(1) and (b)(2) classes, effectively imposing a predominance requirement where the drafters of Rule 23 chose not to include one.").

250 Leatherman v. Tarrant Cnty. Narcotics Intelligence \& Coordination Unit, 507 U.S. 
commonality will inevitably impact how the common question requirement is treated in other contexts, namely Rule 20 (permissive joinder), Rule 24 (intervention), Rule 42 (consolidation), and the multidistrict litigation statute. ${ }^{251}$ Such an eventuality would be unfortunate, as it would broaden the move toward restrictiveness beyond the class action context and run counter to the liberal joinder policy of the Federal Rules. ${ }^{252}$

What the Court has done in Dukes is quite dismaying. The members of the Dukes majority - a collection of jurists who typically extoll the virtues of judicial restraint, ${ }^{253}$ the supremacy of codified texts, ${ }^{254}$ and the detached neutrality with which they exercise their craft ${ }^{255}$ - are either insincere or simply oblivious to their own hypocrisy. To take a requirement that there be "questions of law or fact common to the class" and declare that "the raising of common 'questions' - even in droves" is not what matters to class certification is a textbook illustration of judicial activism that departs from the plain meaning of the text. How can the raising of common questions "in droves" not matter to the issue of whether "there are questions of law or fact common to the class"? Instead, the Dukes majority decided that commonality "requires the plaintiff to demonstrate that the class members "have suffered the same injury" and that the common questions be "central to the validity of each one of the claims." 256 Where does it say that in the rule? As the sometimestextualist Justice Scalia would retort: it doesn't.

Although it is in vogue for the Justices to declare the irrelevance of law review articles, ${ }^{257}$ it is hoped that this writing will lead the Court to reconsider

163,168 (1993).

251 See 28 U.S.C. $\$ 1407$ (a) (2006).

252 See Charles E. Clark \& James W. Moore, A New Federal Civil Procedure, 44 YalE L.J. 387, 1291 (1935).

${ }^{253}$ Chief Justice Roberts, prior to joining the Supreme Court, drafted an article that extolled the virtues of judicial restraint. John Roberts, Jr., Draft Article on Judicial Restraint 1 (undated) (on file with the National Archives), available at http://www.archives.gov/news /john-roberts/accession-60-89-0372/doc006.pdf.

254 See, e.g., Scalia, supra note 1, at 22.

255 See John Roberts, Jr., Opening Statement Before the Senate Judiciary Committee (Sept. 12, 2005) (transcript available at http://www.usatoday.com/news/washington/2005-09 -12-roberts-fulltext_x.htm) (“Judges are like umpires. Umpires don't make the rules; they apply them."); id. ("I will remember that it's my job to call balls and strikes and not to pitch or bat.").

256 Wal-Mart Stores, Inc. v. Dukes, 131 S. Ct. 2541, 2553 (2011) (quoting Gen. Tel. Co. of the Sw. v. Falcon, 457 U.S. 147, 157-58 (1982) (speaking of "the existence of a class of persons who have suffered the same injury as that individual, such that the individual's claim and the class claims will share common questions of law or fact and that the individual's claim will be typical of the class claims")).

257 Chief Justice Roberts was recently dismissive of law review articles when he said: Pick up a copy of any law review that you see, and the first article is likely to be, you know, the influence of Immanuel Kant on evidentiary approaches in 18th Century 
the error of its approach to commonality. Doing so would be a simple matter of applying the plain language of the rule. The Court should save its judgments regarding the weight and import of the common questions for the predominance assessment of Rule 23(b)(3). It is in that context, not commonality, that courts are free to discount "droves" of common questions if the conclusion that distinct questions are more significant is compelling. If confining the predominance inquiry to Rule 23(b)(3) is not satisfying from a policy perspective, however, then supporters of that view should propose that Rule 23(a)(2) be amended to reflect that position. But, as Justice Scalia would typically agree, the rule should not be "interpreted" to mean something that it does not say. ${ }^{258}$ We have already been down that road with Rule 8(a) and the newfound "plausibility" requirement. ${ }^{259}$ Otherwise, in addition to the Advisory Committee Notes that follow the rule, publishers will need to insert the real version of the rules as imagined by the Court so that judges and practitioners will have clearer notice of the actual standards with which they will be expected to comply. ${ }^{260}$

Friends of the rule of law and access to justice should be alarmed by what the Court has done here. As Chief Justice John Roberts once rightly stated:

The greatest threat to judicial independence occurs when the courts flout the basis for their independence by exceeding their constitutionally limited role and the bounds of their expertise by engaging in policymaking committed to the elected branches or the states. When courts fail to exercise self-restraint and instead enter the political realms reserved to the elected branches, they subject themselves to the political pressure endemic to that arena and invite popular attack. ${ }^{261}$

Along the same lines, then-Justice Stone once said of the Court, "the only check upon our own exercise of power is our own sense of self-restraint."262 When that sole check erodes, popular faith in the Court risks being

Bulgaria, or something, which I'm sure was of great interest to the academic that wrote it, but isn't of much help to the bar.

John Roberts, Jr., Remarks at the Fourth Circuit Court of Appeals Judicial Conference (June 25, 201 1) (video recording available at http://www.c-span.org/Events/Annual-Fourth-Circui t-Court-of-Appeals-Conference/10737422476-1/).

258 See Nat'l Fed'n of Indep. Bus. v. Sebelius, 132 S. Ct. 2566, 2655 (2012) (Scalia, Kennedy, Thomas \& Alito, JJ., dissenting) ("[T]o say that the Individual Mandate merely imposes a tax is not to interpret the statute but to rewrite it.").

259 See Ashcroft v. Iqbal, 556 U.S. 662, 677-87 (2009); Bell Atlantic Corp. v. Twombly, 550 U.S. 544, 570 (2007); note 172 and accompanying text.

260 See generally Effron, supra note 127 (discussing the "shadow rules" of joinder); Walker, supra note 185 (discussing the background, common law doctrines that give us the "other" Federal Rules of Civil Procedure).

261 Roberts, supra note 253, at 3.

262 United States v. Butler, 297 U.S. 1, 79 (1936) (Stone, J., dissenting). 
diminished. ${ }^{263}$ Although we deal here not with a statute produced by the political branches but rather codified rules largely superintended by the Court itself through the rulemaking process, Chief Justice Roberts and then-Justice Stone's admonitions for self-restraint remain apropos. For though the rulemaking process is less democratic, it is statutorily prescribed and subject to input and public debate, including the opportunity for a congressional veto. ${ }^{264}$ The Court has no right to flout this process, which is precisely what it has done here. Hopefully, lower courts can attempt some circumspection in approaching commonality after Dukes, hewing more closely to the text of Rule 23(a)(2) than did Justice Scalia. Even better would be for the Court itself to reconsider its decision and restore commonality to the meaning embodied in the language and history behind Rule 23.

263 Although the reasons may not, with any precision, be ascertained, the Supreme Court's popularity has plummeted in recent years, which at a minimum reflects a lowering of public confidence in the Court. See Linda Feldmann, Supreme Court Popularity Hits a Niew Low. Will Obama Attack?, Christian SCI. MONITOR (May 1, 2012), http://www.csmonitor.com/USA/2012/0501/Supreme-Court-popularity-hits-new-low.-WillObama-attack ("Only 52 percent of the American public has a favorable opinion of the court, down from 64 percent three years ago and a high of 80 percent favorability in 1994, Pew [Research Center] reported on Tuesday.").

26428 U.S.C. $\S \S 2072-2074$ (2006). 
BOSTON UNIVERSITY LAW REVIEW 